\title{
Unequal inequalities? How participatory inequalities affect democratic legitimacy
}

\section{Manuscript accepted for publication in European Political Science Review}

\author{
Authors (listed alphabetically and contributed equally): \\ Henrik Serup Christensen, Political Science, Åbo Akademi University (henrik.christensen@abo.fi) \\ ORCID: https://orcid.org/0000-0003-2916-0561
}

Janette Huttunen, Samforsk, Åbo Akademi University

ORCID: https://orcid.org/0000-0003-0683-9344

Fredrik Malmberg, Political Science, Åbo Akademi University

ORCID: https://orcid.org/0000-0001-8113-6222

Nanuli Silagadze Samforsk, Åbo Akademi University

ORCID: https://orcid.org/0000-0003-2162-144X

\begin{abstract}
Democratic theorists have long emphasized the importance of participatory equality, i.e. that all citizens should have an equal right to participate. It is still unclear, however, whether ordinary citizens view this principle as central to democracy and how different violations of this principle affect subjective democratic legitimacy. The attitudes of citizens are imperative when it comes to the subjective legitimacy of democratic systems, and it is therefore important to examine how participatory inequalities affect these attitudes. We bere contribute to this research agenda with survey experiments embedded in two surveys $(n=324, n=840)$. We here examine 1) whether citizens consider participatory inequality to be an important democratic principle, and 2) how gender and educational inequalities affect subjective legitimacy and the perceived usefulness of the participatory input. The results show that citizens generally consider participatory inequalities to be important, but only gender inequalities affect subjective legitimacy and usefulness. Hence it is important to consider the type of inequality to understand the implications.
\end{abstract}

Key words: Political equality, Gender inequality, Education, Legitimacy, Political participation, Survey experiments 


\section{Introduction}

That all citizens are equal is a central democratic ideal, but some citizens are still more equal than others. Studies show that inequality influences the functioning of democracy by affecting key political attitudes (Andersen and Fetner, 2008), public attitudes toward minorities (Andersen \& Fetner, 2008), and political behaviour (Solt, 2008). The last point is a particular worry for the present purposes, since studies show persistent differences in who takes advantage of the formal equal right to participate (Verba, Schlozman and Brady, 1995; Verba, 2003; Armingeon and Schädel, 2015; Dalton, 2017).

We here focus on inequalities in participatory processes, by which we mean the extent to which groups in society are represented equally in participatory processes such as referendums and citizen assemblies. While participatory equality both from a theoretical and empirical perspective is a cornerstone of democracy, it is still unclear what ordinary citizens think about this principle. Research on public opinion concerning political (in)equality is surprisingly scarce, perhaps because scholars often take for granted that the public supports an equal voice for all citizens (Howarth et al., 2019, p. 200). The studies that do exist mainly examine whether equality is realized in practice based on differences in electoral turnouts or other forms of political participation across social groups (Verba, Schlozman and Brady, 1995; Verba, 2003). While these studies make valuable contributions, it is also important to examine how participatory inequality affect decision-making legitimacy in the eyes of the public. Studies indicate that many are unwilling to take an active role in politics, even when they believe that citizens should have an equal right to participate (Hibbing and Theiss-Morse, 2002; Bengtsson and Christensen, 2016; Fernández-Martínez and Font, 2018). Such convictions could entail that they do not see participatory inequality as a problem for democracy. It is therefore important to examine whether citizens consider participatory equality to be an essential democratic ideal. 
While much of the discussion on participatory inequalities focus on elections and parliaments (Atkeson and Carrillo, 2007; Espírito-Santo, 2016; Beauvais, 2021), the representation of disadvantaged groups in participatory processes is also critical for sustaining democratic legitimacy (Karpowitz, Raphael and Hammond, 2009; Karpowitz, Mendelberg and Shaker, 2012; Beauvais, 2020; Afsahi, 2022). For such participatory processes to help regenerate legitimacy, it is necessary that they are seen as improving on existing inequalities.

Consequently, it is imperative to examine how participatory inequalities in participatory processes affect the legitimacy of political decision-making. Studies suggest that gender inequality has detrimental effects on the legitimacy of political decisions (Clayton, O'Brien and Piscopo, 2019), but other inequalities can have less severe effects (Mayne and Peters, 2022). Furthermore, the effects may differ depending on the type of legitimacy at stake (Scharpf, 1999; Schmidt, 2013). Finally, the impact of inequalities might be contingent on the nature of the decisions (Silagadze et al., 2022) and the type of participatory process (el-Wakil and Strebel, 2022). It is crucial to examine the interplay between these factors to appreciate how participatory inequalities affect legitimacy.

In this article, we examine attitudes towards inequality and their implications for democratic legitimacy with the help of two studies. First, we assess the extent to which citizens demand participatory equality with the help of both explicit questions and a list experiment $(n=324)$. By giving citizens the chance to express their true preference without admitting to holding socially unacceptable opinions, we provide a stern test of whether citizens consider participatory equality to be important. In a second study ( $n=840)$, we examine the interplay between different factors in shaping the impact. In addition to gender inequalities, we examine the impact of inequalities in educational attainment to see whether this has similar effects. We here distinguish between the impact on input legitimacy in the form of subjective legitimacy of the decision-making process, and output legitimacy in the form of the perceived 
usefulness of the output of the participatory process. Finally, we consider whether the effects are moderated by issue consequences (personal or society at large) or type of participatory process (referendum or advisory assembly). Both studies are conducted in Finland, a context where equality is the dominant norm, which means we should be able to detect the impact of inequalities.

Our results show that people do value equality as a democratic ideal. We find that it has a negative effect on legitimacy when women are underrepresented, whereas educational inequalities do not have a similar negative effect. Furthermore, these differences are similar across issue consequences and the type of participatory process. All of this suggests that while participatory equality is indeed an essential democratic ideal among citizens, it is necessary to consider the type of inequality to understand the implications for legitimacy.

\section{Popular perceptions of participatory inequalities}

The principle of political equality expresses a moral judgement where the good of every human being ought to be regarded as intrinsically equal to the good of anybody else, which implies that government should give equal consideration to the good and interests of every person (Dahl, 1998).

One of the essential merits of democracy is its intrinsic capacity of yielding more legitimate decisions by giving citizens equal voice in the decision-making process (Dahl, 1989). This principle is in existing democracies enshrined in the one person, one vote principle. Nevertheless, this formal equality does not necessarily entail that all citizens also take advantage of this right in equal terms. Several studies show persistent inequalities in political participation in elections and between elections (Verba, Schlozman and Brady, 1995; Armingeon and Schädel, 2015; Dalton, 2017). Verba et al. (1995) find that these participatory inequalities have their roots in differences in individual resources, psychological engagement 
and networks. Dalton (2017) contends that the expansion of participation in old and new forms creates a widening participation gap, and that education plays a key role in explaining this gap. When it comes to elections, education attainment is also considered a main driver for the participatory gap between social groups that has widened over the past decades (Armingeon and Schädel, 2015).

Groups with more resources, be they intellectual, economic or organizational, are not only likely to be more active, they are also more likely to be heard by decision-makers (Gilens, 2005). Empirically, it has also been found that inequalities hampers the proper functioning of democracy (Andersen and Fetner, 2008; Anderson and Singer, 2008; Solt, 2008). This is worrisome from a normative perspective, since it hampers democratic inclusiveness (Young, 2000). Furthermore, descriptive representation promotes decision acceptability and legitimacy of policy outcomes since people are more willing to accept a decision when it is made by a group of people that resemble themselves (Arnesen and Peters, 2018).

Considering the emphasis on participatory inequality in existing literature, it is somewhat surprising that few studies have examined attitudes towards such inequalities. One of the early survey-based studies to do so was Prothro \& Grigg (1960), who found overwhelming support among Americans for the proposition that all citizens should have an equal chance to influence government policy. Later studies on how people evaluate democracy focus on formal forms of equality before the law and social and economic equality (Ferrín and Kriesi, 2016). This may be because it is taken for granted that the public supports an equal voice for all citizens (Howarth et al., 2019: 200). It can also be problematic to examine this with traditional survey items since respondents tend to rate all elements of democracy highly when asked directly (Ferrín and Kriesi, 2016). To some extent, all democratic ideals are important. But this result might also be due to social desirability bias, which concerns the tendency of individuals to give answers that are perceived as more favourable (Nederhof, 1985; Krumpal, 
2013). It can be perceived as sensitive to disregard an established democratic ideal when the respondent is aware that this is considered important by others.

It may therefore be beneficial to use more subtle techniques when asking people to reveal their preferences for participatory equality.

However, a more substantial reason can also explain why people should not consider participatory equality to be important for a functioning democracy. Studies show support for a stealth model of democracy across several countries, which entails that ordinary citizens should not necessarily be involved in political matters on a regular basis (Hibbing and TheissMorse, 2002; Bengtsson and Mattila, 2009; VanderMolen, 2017; Fernández-Martínez and Font, 2018). This point of view entails that instead of popular involvement, elected elites and/or experts should make the important decisions. Involvement for ordinary citizens should be reserved to extraordinary circumstances when the system clearly no longer contributes to the benefit of all. Crucially, studies show that these ideals also have consequences for how active citizens are in political participation (Bengtsson and Christensen, 2016; Gherghina and Geissel, 2017). Consequently, people supporting stealth democracy are also likely to consider participatory inequalities to be less of a concern from a democratic perspective. Since widespread participation is not necessarily considered beneficial, it is necessary to examine whether people consider participatory equality important for democracy. This leads us to our first hypothesis:

H1. People consider participatory equality to be an important democratic ideal.

We examine this proposition in our first study with the help of both explicit questions and a list experiment to investigate whether results are affected by social desirability bias. 


\section{Participatory inequalities and implications for legitimacy}

Even when people believe that participatory inequalities matter for democracy, the implications for the legitimacy of decision-making depend on several factors. For example, the inclusion of women in participatory processes is likely to be more important to women since it boosts their descriptive representation in the processes (Pitkin, 1967; Clayton, O'Brien and Piscopo, 2019). We examine how over- or under-representing certain groups affect the legitimacy of the outcomes of participatory processes, and the extent to which these effects are contingent on the nature of the issue and the type of participatory process. In the following, we propose several hypotheses that are examined in study 2 .

First, it is important to recognize that different kinds of participatory inequality may have entirely different implications for legitimacy. The inclusion of representatives from historically underrepresented groups help legitimize political decisions (Clayton, O'Brien and Piscopo, 2019). But there are many different potential groups, and all do not play an equally important role in enhancing legitimacy. We here focus on two different forms of inequality: gender inequalities and inequalities in educational attainment. While the list of potential inequalities to include is virtually endless, these have received considerable attention in the literature on participatory inequalities and are widely recognised as individual-level factors that affect political participation.

A wide array of studies on gender inequalities in different forms of political participation provide evidence of consistent evidence of gender differences in participation (Schlozman, Burns and Verba, 1994; Karpowitz, Mendelberg and Shaker, 2012; Bolzendahl and Coffe, 2013). Schlozman et al. (1994) show that men are more active in traditional political activities. Bolzendahl and Coffé (2013) also find that men are more active in traditional political activities, but that women are more active in individualized activities such as signing petitions or political consumerism. A similar pattern exists when examining participation among 
younger citizens (Grasso and Smith, 2022), as young women are more active in petitioning and boycotting, whereas young men are more active in political parties and organizations. Gender differences have also been found in participatory processes such as deliberative minipublics (Karpowitz, Mendelberg and Shaker, 2012). A study suggests that women are more willing to deliberate, but their efforts are undermined by men's negative deliberative behaviours (Afsahi, 2022). The impact of participation may be gendered too, since Beauvais (2020) finds that people are more willing to revise their opinions after hearing a man's counterargument than after hearing an identical counterargument from a woman. While gender differences in participation are today less pronounced than previously (Burns, 2007; Coffé and Bolzendahl, 2010), it is a cleavage that cuts across other areas of stratification, which makes it salient for all citizens (Coffé and Bolzendahl, 2010, p. 318).

Gender inequalities are also important due to descriptive representation (Rosenthal, 1995; Atkeson and Carrillo, 2007; Clayton, O'Brien and Piscopo, 2019). Several factors such as age, party identification, and gender stereotypes help explain attitudes towards women's descriptive representation (Sanbonmatsu, 2003; Dolan and Sanbonmatsu, 2009; Dolan, 2010). A recent study contends that concerns with the adequate representation of women's interests explain women's support for gender equality, whereas this has no effect among men (EspíritoSanto, 2016). According to Clayton et al. (2019), gender inequalities in participatory processes suppress the legitimacy of decision-making in the US across issues and policy outcomes. Women's presence contributes to higher procedural legitimacy when the issue under discussion is unrelated to gender or even if decisions go against women's interests, whereas levels of procedural fairness, institutional trust, and acquiescence are lower if all-male panels advance feminist policies. All of this shows that the inclusion of women matters for perceptions of decision-making legitimacy. 
Education is usually seen as arguably the strongest predictor of political participation, since those with more education are more likely to be politically active (Verba, Schlozman and Brady, 1995; Dalton, 2017; Mayne and Peters, 2022). Education can boost participation by helping to develop pertinent skills for participation and provide concrete information on how society and politics function (Verba, Schlozman and Brady, 1995). Furthermore, educational attainment cuts across other cleavages, such as income, and children born to affluent and well-educated parents are for instance known to be more likely to become well-educated and affluent themselves (Bowles, Gintis and Groves, 2005). Although Finland is a country with strong educational equity on the basic level (Ustun \& Eryilmaz, 2018), there has been substantial differences in turnout depending on level of education, especially among the young age groups (Lahtinen, 2019), showing that educational inequalities have real consequences for political engagement, even in Finland.

Since educational attainment remains a strong source of participatory inequality in contemporary democracies, it is important to examine whether this also has a detrimental effect on democratic legitimacy. Here it is interesting to note that a recent study suggests that education-based differences are relatively unimportant for perceptions of legitimacy (Mayne and Peters, 2022). On the other hand, the increased emphasis on education as the key to success in society has been questioned (Sandel, 2021). Furthermore, education has become a key explanation for a contemporary cleavage between the winners and losers of globalization (Stubager, 2010; Kriesi et al., 2012). Hence, there is reason to believe that educational inequalities may affect legitimacy.

Based on this, we propose the following two hypotheses:

H2a. The perceived legitimacy of participation is lower when men are overrepresented.

H2b. The perceived legitimacy of participation is lower when the well-educated are overrepresented. 
We here use overrepresented to indicate that men/well-educated are represented in greater numbers than in the general population.

Legitimacy is also a multidimensional concept with different meanings that is difficult to measure unequivocally (Weatherford, 1992; Gilley, 2006; Tyler, Feldman and Rasinski, 2006; Arnesen and Peters, 2018). Our focus in the previous set of hypotheses is on how inequalities affect citizens' perceptions of input legitimacy of participatory processes. There are however studies that suggest that people care more about output legitimacy, or the extent to which decisions correspond to citizens' policy preferences (Scharpf, 1999; Schmidt, 2013; Esaiasson, Gilljam and Persson, 2017). We here refer to this as the usefulness of the advice since we do not study the impact of the policies in question. Output legitimacy conflict with input legitimacy since people may be willing to accept participatory inequalities when it is believed that those who are overrepresented can assure better policy outcomes. Since education can help develop civic skills and make participants better moral reasoners, increasing the proportion of participants with low education can lower the quality of participation, hence making outcomes less useful (Verba, 2003, p. 669). When people were to believe this to be true, they may well accept that the well-educated form the majority since it can make the participatory input more useful for decision-makers. While gender does not confer similar advantages, people use certain cues to infer traits or policy positions about representatives (Carnes and Sadin, 2015; Arnesen, Duell and Johannesson, 2019; Däubler, Quoß and Rudolph, 2021). Since men have historically held more civic resources than women (Burns, 2007), people might, even subconsciously, still believe that men are also more apt at political decision-making (Rashotte and Webster, 2005; Dolan, 2010). Such perceptions can endure even in a relatively gender-equal society such as Finland, where only 44 per cent of men and 52 per cent of women find both genders equally apt in all policy areas (Nieminen \& Attila, 2018). We therefore propose the following two hypotheses regarding the usefulness of participation when advantaged groups are overrepresented: 
H3a. Output legitimacy in the form of perceived usefulness of participation is higher when men are overrepresented.

H3b. Output legitimacy in the form of perceived usefulness of participation is higher when the well-educated are overrepresented.

Two more aspects are worth considering for the present purposes: the form of participatory process and the issue consequences since both are likely to moderate how participatory inequalities affect perceived legitimacy and usefulness.

Although much research on equality is focused on elections and parliaments, there is also a need to scrutinize equality in participatory processes that give citizens a voice between elections. As noted by Clayton et al. (2019, pp. 128-129), who in their study focus exclusively on deliberative bodies, the nature of citizen involvement and decision-making rules are likely to affect the results. Various forms of participatory processes exist (Fung, 2003; Smith, 2009), but they can be divided into two broad categories (LeDuc, 2015; el-Wakil and Strebel, 2022): 1. Direct-democratic processes that include a vote-centric conception of democracy where citizens make decisions directly (Altman, 2011; Qvortrup, 2013), and 2. deliberative processes, which are based on a talk-centric conception of democracy where citizens rarely make any final decisions, but instead provide advice to formal decision-makers by discussing issues to achieve an enlightened understanding (Grönlund, Bächtiger and Setälä, 2014). Although nuances exist, these two types of participatory processes exemplify important differences in how to involve citizens (el-Wakil and Strebel, 2022). For the current purposes, it is worth noting that direct democracy frequently involves the use of referendums where citizens decide on issues by casting a vote (Altman, 2011; Silagadze and Gherghina, 2018). ${ }^{1}$ Deliberative processes, on the other hand, most often consist of different types of institutional

\footnotetext{
${ }^{1}$ While referendums are often formally advisory, at least in Finland they are often considered politically binding in practice since going against the will of the people is politically untenable (Jäske, 2017).
} 
bodies where ordinary citizens discuss in smaller groups and provide an output that can be used as guidance by formal decision-makers and/or the general public (Grönlund, Bächtiger and Setälä, 2014). Since people are expected to care about policy outcomes (Arnesen, 2017; Werner and Marien, 2020), it is likely that they will care more about inequalities in participatory processes where participants have a direct say in the outcome. Hence, political inequalities may be expected to be more concerning in referendums that are usually more decisive compared to discussion forums of a more advisory nature.

H4. Differences in subjective legitimacy and perceived usefulness are more pronounced for referendums compared to discussion forums.

Finally, we examine how the consequences of issues moderate how inequalities affect perceptions of legitimacy and usefulness. Several studies demonstrate that outcomes matter to perceptions of decision-making legitimacy (Arnesen, 2017; Esaiasson, Gilljam and Persson, 2017; Christensen, Himmelroos and Setälä, 2020; Werner and Marien, 2020, 2020). While the direct effect of outcome favourability on legitimacy is hardly disputable, the nature of the outcome can even have an indirect effect on how inequalities affect perceptions of legitimacy. We here follow the work of Kinder and Kiewiet (1981), who distinguish between sociotropic voters who care more about the economic situation of the nation, and egocentric voters, who use their personal situation to decide how to cast their vote. This distinction has also been used to explore the sources of public opposition to immigration (Solodoch, 2020). Following this line of reasoning, we assume that people evaluate political decisions either based on their perceived consequences for society at large, or their consequences for the individual in question. A recent study shows that sociotropic and egocentric perceptions of social inequalities has different associations with political participation since people with higher levels of sociotropic concerns about inequalities are more likely to take action (Silagadze et al., 2022). Other studies suggest that self-interest plays a larger role when the policy stakes 
for the individual are great, clear and salient (Chong, Citrin and Conley, 2001; Haselswerdt, 2020). All of this shows that whether the issue at hand concern personal matters or society at large is likely to have implications for how inequalities affect both aspects of legitimacy. Based on this, we base our final hypothesis on the assumption that effects of inequalities are stronger when personal issues are at stake rather than societal matters:

\section{H5. Differences in subjective legitimacy and perceived usefulness are more pronounced} when decisions concern personal issues rather than societal issues.

In the following, we outline how we examine these hypotheses in our studies.

\section{Data and variables}

To examine our hypotheses, we conducted two separate studies with survey experiments in Finland. Finland is an established Nordic democracy with strong egalitarian values and consensual political decision-making are dominant norms (Inglehart and Norris, 2003; Karvonen, 2014). At the same time, citizens exhibit high levels of satisfaction with democracy and institutional trust (Rapeli \& Koskimaa, 2020; Bäck et al., 2016; Kestilä-Kekkonen \& Söderlund, 2016), and citizens can engage in various participatory processes, such as the Citizens' initiative (Huttunen and Christensen, 2020). Finland scores high in gender equality (Inglehart and Norris, 2003; OECD, 2018) and in education (OECD, 2021). Nevertheless, reports indicate that a large portion of Finnish people believe that inequalities persist (Nieminen \& Attila, 2018). Finland thereby provides an interesting contrast to the US, where most existing studies have been carried out. The pervasive equality in Finland is likely to strengthen the negative impact of participatory inequalities since they transgress established societal norms. Finland may therefore be considered a "most-likely case" (Eckstein, 1975), since it provides a case where the theoretical relationships are likely to exist. 
The data for both studies were collected 19-27 May 2021. For study 1, 324 respondents filled in the survey while 840 respondents filled in the survey for Study 2. We did a priori power analyses with G*Power 3.1 to establish the necessary number of respondents (Faul et al., 2009). For study 1,146 respondents equally distributed between the groups should be enough to detect significant differences between the two groups with a statistical power of 0.9 when the expected mean is 3.0 in the control group (where 3 genuine democratic ideals/threats are presented) and 4.0 in the treatment group (where we include "equal participation for all citizens" in addition to the same three democratic ideals or "Inequalities in the political participation of citizens" as an additional potential threat), even when we assume a high SD of 2.0. To ensure that potential null results are not due to a low number of respondents, we set the target to 300 respondents and received 324 completed survey responses. Hence we are able to detect mean differences with a high level of power, although the number of respondents is insufficient to explore differences across respondents' characteristics (Ahlquist, 2018). For study 2, 523 respondents give a power of 0.90 for a factorial ANOVA with main effects and interaction effects when we assume an effect size of 0.20 (medium) and alpha $=0.05$. We set the target to 800 respondents to be certain we have sufficient power and achieved 840 completed survey responses.

The respondents for both studies were recruited from online panels via Qualtrics. We used quotas to ensure that respondents in both studies reflected the Finnish population when it comes to age, gender, and place of living. Furthermore, respondents were not allowed to take part in both studies to avoid contamination. Information on the characteristics of both samples and the general population is found in Appendix 1.

In Study 1, we examine $\mathrm{H} 1$ on general attitudes toward political inequality with the help of direct questions on evaluations of various democratic ideals, including participatory equality. Here respondents on a scale 0-10 (10 most important) rated the subjective importance of 
common democratic ideals: Equality in the possibility for political participation; Free and fair democratic elections; Opposition parties can freely criticise the government; Free media can freely criticise the government; and Government works to reduce income inequalities.

Since examining peoples' attitudes to democratic ideals in surveys is likely to suffer from social desirability bias, we also included two list experiments (LE1 and LE2) that were pre-registered for hypotheses, data collection and analysis at https://osf.io/4nbcz/?view only=12857ff47f1342febcd8c02de07d4f3a. Deviations from the pre-registration are noted in Appendix 2. We included two list experiments to be able to discern both whether people consider participatory equality to be imperative for having a proper democracy (LE1) and whether participatory inequality is considered a danger to the survival of democracy (LE2). In LE1, the sensitive item is "Equal participation of all citizens" while in LE2 it is "Inequalities in the participation of citizens". The treatments here are broad since we do not mention specific forms of participation, but this is intentional since we here aim to examine the impact of participatory inequalities broadly conceived, while we focus on more specific effects in Study 2. Although the two list experiments have similar aims, we considered them sufficiently different so both experiments were randomized completely, meaning an individual could be in the treatment group twice.

The list experiment or item count technique is a technique that makes it possible to examine whether people value equality as an important part of democracy even when there is no pressure from social desirability bias as the sensitive question is asked in an indirect fashion (Blair and Imai, 2012; Blair, Imai and Lyall, 2014). In list experiments, a survey sample is split into randomly assigned treatment and control groups, which are given the same question. The respondents in the treatment group are presented a list including a sensitive item with several non-sensitive items, while the control group is presented with a list with only the non-sensitive item, and possibly a placebo item to ensure that the number of items is identical (Riambau 
and Ostwald, 2021). We also include rare items in both groups to avoid ceiling effects that could entail that people feel that their true preferences are exposed (Glynn, 2013). The respondents are asked to indicate how many of the items on the list they agree with or apply to them without indicating which ones, thereby making it possible to answer without selecting the sensitive item. Any differences in mean scores can therefore be attributed to the sensitive item (Kramon and Weghorst, 2019). Table 1 shows the contents of each of the list experiments.

Table 1. Outline of list experiments.

\begin{tabular}{|c|c|c|}
\hline & List experiment 1 (LE1) & List experiment 2 (LE2) \\
\hline Introduction & $\begin{array}{l}\text { In the following is a list of five norms that } \\
\text { may or may not be considered imperative } \\
\text { for having a proper democracy. Please } \\
\text { write the number of norms that you believe } \\
\text { are essential for a proper democratic } \\
\text { system. You should not write what norms, } \\
\text { only how many of these you believe are } \\
\text { essential. }\end{array}$ & $\begin{array}{l}\text { Next, we would instead like to know how } \\
\text { many of the following occurrences you } \\
\text { believe are a potential danger to the } \\
\text { existence of democracy. Again, you should } \\
\text { not write which occurrences you see as a } \\
\text { danger, only how many. }\end{array}$ \\
\hline Nonsensitive item 1 & Free and fair elections & $\begin{array}{l}\text { Violence against opposition } \\
\text { leaders }\end{array}$ \\
\hline Nonsensitive item 2 & Freedom of speech & $\begin{array}{l}\text { Unelected elites secretly make } \\
\text { important decisions }\end{array}$ \\
\hline Nonsensitive item 2 & The right to vote & $\begin{array}{l}\text { Parliament decides to } \\
\text { abandon upcoming elections }\end{array}$ \\
\hline Rare item (to avoid ceiling effects) & Unlimited welfare benefits & Unemployment benefits \\
\hline Placebo (only control group) & Violence against the opposition & Free and fair elections \\
\hline $\begin{array}{l}\text { Treatment (only treatment } \\
\text { group) }\end{array}$ & Equal participation for citizens & $\begin{array}{l}\text { Inequalities in the political } \\
\text { participation of citizens }\end{array}$ \\
\hline Total $n$ & 324 & 324 \\
\hline Treatment $n$ & 160 & 164 \\
\hline Control $n$ & 164 & 160 \\
\hline
\end{tabular}

Since our main interest here lies in establishing differences between treatment and control groups rather than individual differences, we follow the advice of Ahlquist (2018) and only analyse the results using a simple difference in mean estimate.

In Study 2, we examine hypotheses $\mathrm{H} 2-\mathrm{H} 5$ with a survey experiment where we with the help of a vignette examine the direct effects of gender and educational inequalities on outcome legitimacy $(\mathrm{H} 2 \mathrm{a}$ and $\mathrm{H} 2 \mathrm{~b})$ and the usefulness $(\mathrm{H} 3 \mathrm{a}$ and $\mathrm{H} 3 \mathrm{~b})$ of the input. Furthermore, we examine whether these associations differ depending on the type of participatory process ( $\mathrm{H} 4$ : 
Referendum or Discussion forum) and the consequences of the issue (H5: egocentric or sociotropic). This study was also preregistered for the hypotheses, data collection and analysis at https://osf.io/rjqux/?view only=03c7b3039ae14b78a5c1fb533537f9c0 and deviations from the pre-registration are again noted in Appendix 2.

In a vignette survey experiment, respondents are provided with a short description of a scenario, where certain factors or treatments are randomly varied. Respondents are then asked to evaluate the scenario described in one or more variables that constitute the dependent variables (Mutz, 2011). By examining differences in the scores across treatments, it is possible to determine the effect of and interplay between all treatments. Such survey experiments thereby combine experimental control of treatments examined on subjects that constitute a representative sample of the population of interest (Mutz, 2011, pp. 1-2).

In study 2, our vignette is worded as follows (Randomized treatments in capital letters):

Imagine that there is a need to update existing legislation concerning an issue with great consequences for YOU PERSONALLY/FOR SOCIETY AT LARGE. To be able to improve existing legislation, the decision-makers want to receive input from the general public. They therefore arrange a REFERENDUM / DISCUSSION FORUM ${ }^{2}$ where all Finnish citizens have a chance to participate. While the aim was to achieve equality in participation, it turns out that a majority of those who took part were MEN/WOMEN with BASIC EDUCATION / UNIVERSITY DEGREE.

The study thus has four treatments that correspond to our hypotheses, each with two values ( $2 \times 2 \times 2 \times 2$ design). The gender inequality treatment concerns whether men or women were

\footnotetext{
2 We use 'Discussion forum' ('keskustelutilaisuus' in Finnish) to make the question more comprehensible for the respondents compared to mini-public or similar terms that are not recognized by most.
} 
overrepresented, while the educational treatment concerns whether people with a basic education or a university degree were overrepresented. The issue treatment concerns whether the consequences affect respondents personally or society at large while the type of participation discerns whether it was a referendum or a discussion forum.

We include two measures that measure the impact on outcome legitimacy:

1. Legitimacy 1: How legitimate do you think this input into the decision-making process is? (Answer on scale 0-100)

2. Legitimacy 2: In your opinion, to what extent should decision-makers follow the advice from this input when making their decision? (Four-graded answer Completely/In most regards / To some extent / Not at all; this was recoded to also vary between 0-100)

Two other measures probe how respondents consider the usefulness of the input:

3. Usefulness 1: How useful do you think the input will be for decision-makers when adopting new legislation? (Answer on scale 0-100)

4. Usefulness 2: How likely do you believe it is that legislation will be improved as a consequence of this input? (Answer on scale 0-100)

The data is analysed with factorial ANOVAs for each of the four outcomes where we include all possible interaction effects to examine moderating effects of the type of participation and the type of issue. ${ }^{3}$

\footnotetext{
${ }^{3}$ We report the results in figures and text, but the full results are in Appendix 4 together with robustness tests where we show ANOVA models with only direct effects and models that only include the interaction effects of direct relevance to the hypotheses. Here we also report mean values and standard deviations for all 16 potential combinations. The substantial interpretations of the models are the same.
} 


\section{Analysis}

We first report the results of the explicit questions in Study 1 on attitudes towards various democratic ideals, including how people perceive the importance of inequalities in political participation.

Figure 1. Violinplots showing answer distributions for rating democratic ideals

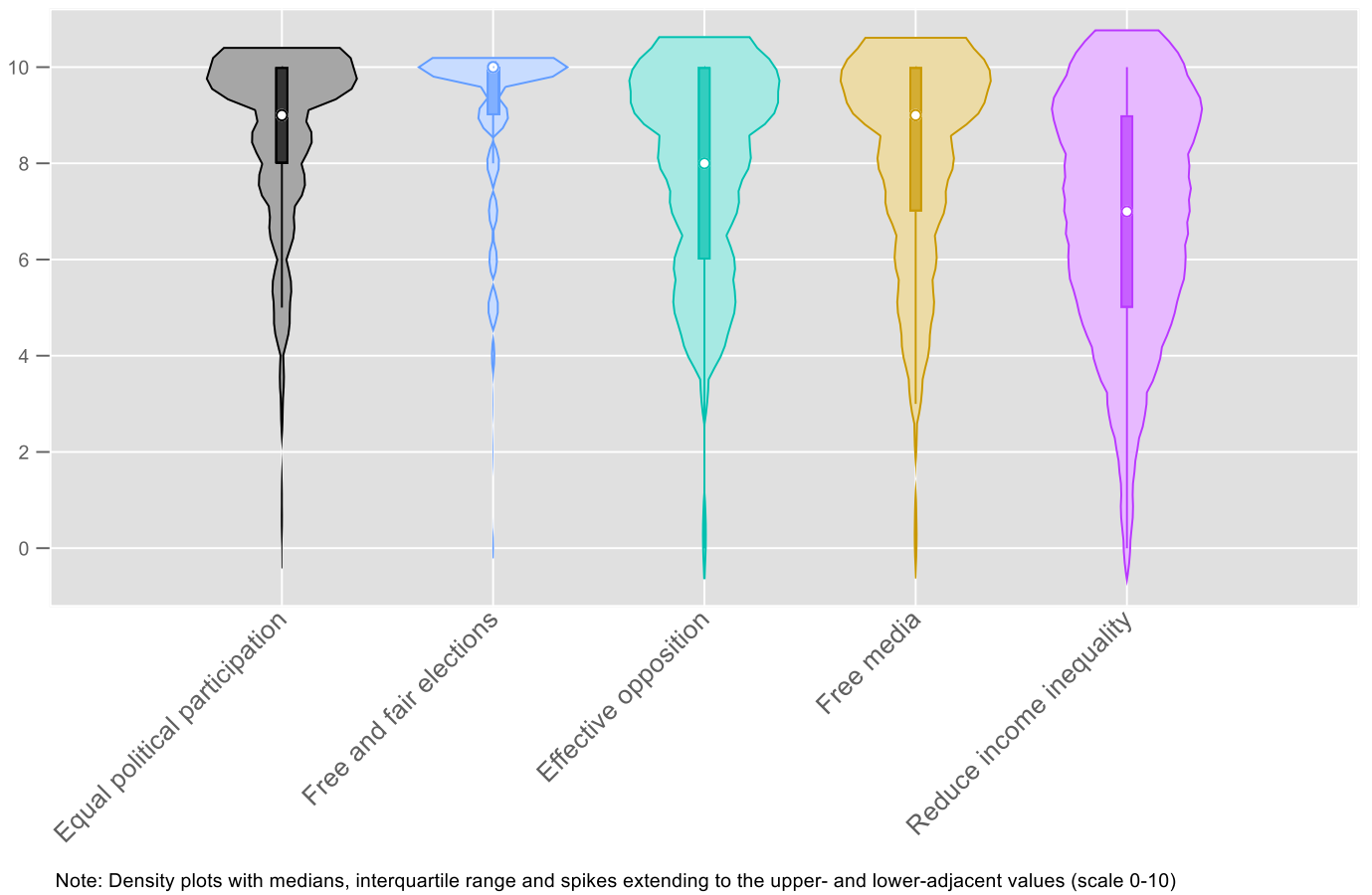

All ideals are popular among respondents as the mean scores range from 6.67 (Standard deviation $(S D)=2.77)$ for reducing income inequalities to $8.99(S D=1.81)$ for Free and fair elections. Equal political participation is second most important $(M=8.61, S D=1.89)$. These results indicate that equality in participation is considered among the most important democratic ideals. 
To examine whether social desirability bias affects the results, we in Table 2 report results from our list experiments that give people the chance to reveal their true preferences. ${ }^{4}$

Table 2. Mean differences between control group and treatment group

\begin{tabular}{lcccc}
\hline & Control mean & Treatment mean & Difference in mean & P-value \\
\hline List experiment 1 (LE1) & $3.13(.08)$ & $4.08(.07)$ & $-0.95(.11)$ & 0.000 \\
List experiment 2 (LE2) & $2.91(.08)$ & $3.36(.09)$ & $-0.45(.12)$ & 0.000 \\
\hline \multicolumn{4}{l}{ Note: Entries are mean values with standard errors in parentheses. P-values are from a tw-sample t-test with equal variance. }
\end{tabular}

The results in LE1 indicates that respondents value equality as a democratic ideal since the mean value is about 1 point higher in the treatment group. In LE2, the mean in the treatment value is 0.45 higher than the control group, which shows that respondents consider inequalities in political participation a threat to democracy, albeit not an imminent one as the difference in mean was smaller than in LE1.

These results support $\mathrm{H} 1$ and suggest that people do consider equality in participation a valuable democratic ideal. The ensuing question is whether the effects on legitimacy depend on various characteristics? We explore this issue in the vignette survey experiment contained in Study 2.

\footnotetext{
${ }^{4}$ The distribution of respondents is in Appendix 3.
} 
Figure 2 Direct effects of gender and educational inequalities on decision-making legitimacy and usefulness of input

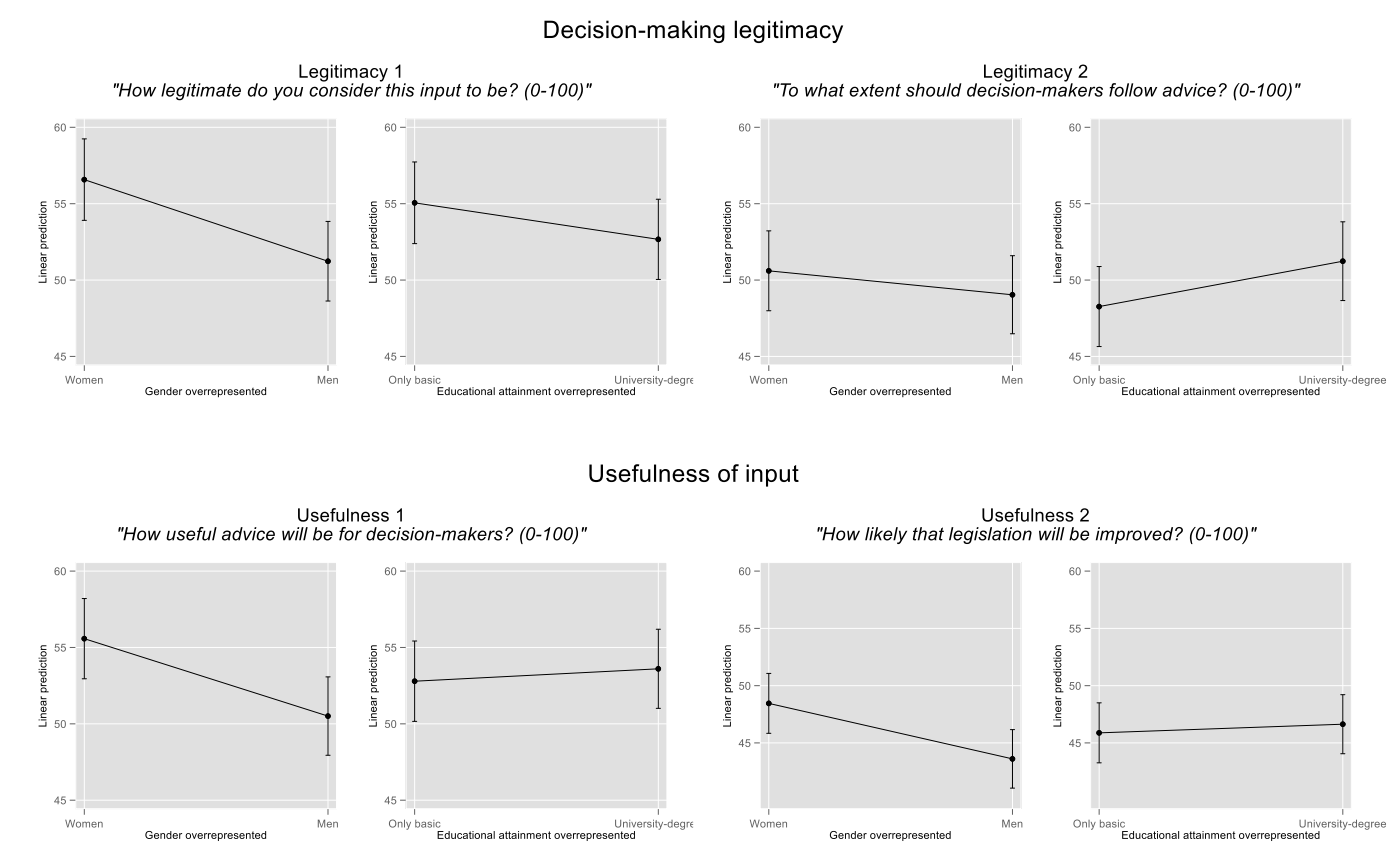

Note: Results represent conditional mean scores on scales $0-100$ with $95 \%$ confidence intervals

Figure 2 shows that both decision-making legitimacy and perceived usefulness is generally lower when men are in majority. Differences are significant for Legitimacy $1(F(1,824)=7.96$, $p=.005)$, Usefulness $1(F(1,824)=6.45, p=0.019)$ and $2(F(1,824)=6.22, p=0.013)$. While the effects are significant, the differences are only about five points on the 0-100 scales, meaning effects sizes are weak, but consistent. As we show later, this is at least partly explained by heterogenous treatment effects across the population. The impact of educational differences is smaller, but there is a weak and insignificant tendency for usefulness to be higher when people with university degrees are overrepresented. The results run in opposite directions for subjective legitimacy, but even here the differences are insignificant. This entails that $\mathrm{H} 2 \mathrm{a}$ is supported, but $\mathrm{H} 2 \mathrm{~b}$ and $\mathrm{H} 3 \mathrm{a}$ and $\mathrm{H} 3 \mathrm{~b}$ are not supported by the evidence. Having a majority of women in participatory processes is generally a good thing for both decision-making 
legitimacy and perceived usefulness of advice, whereas there are no clear gains when educational groups are over- or under-represented. ${ }^{5}$

In Figure 3 and Figure 4 we show results concerning conditional effects depending on type of participation and type of issue consequence.

\section{Figure 3. Differences in effects across type of participatory process}

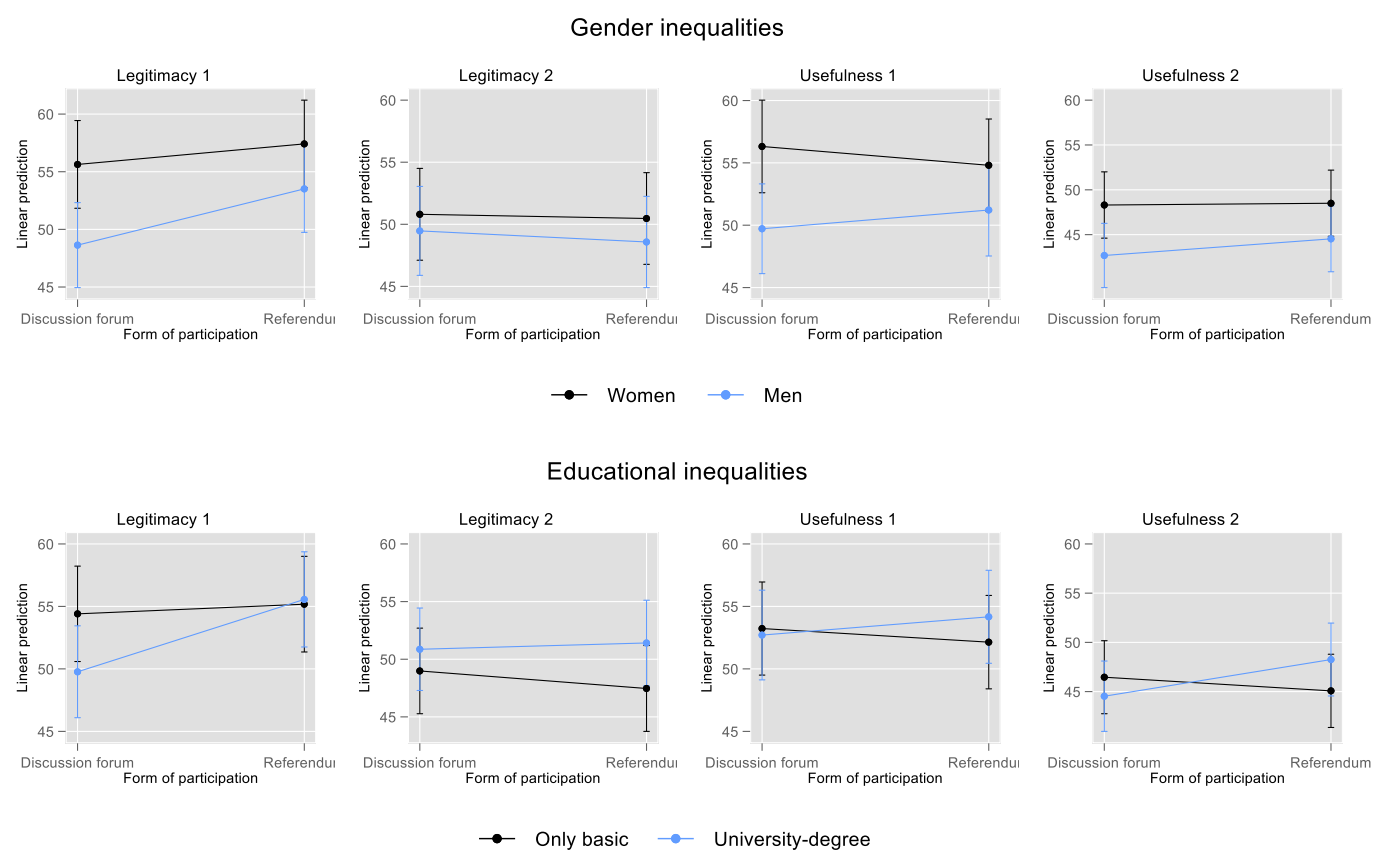

Note: Results represent differences in conditional mean scores depending on type of participatory process on scales $0-100$ with $95 \%$ confidence intervals

The differences across type of participation are small and conflicting regardless of the type of measure and whether we examine gender inequalities or educational inequalities. None of the relevant interaction terms are even close to significance, all of which shows that the effects are consistent across type of participation, contrary to $\mathrm{H} 4$.

\footnotetext{
${ }^{5} \mathrm{~A}$ reasonable assumption might be that there is an interplay between the two forms of inequalities, so the effects are different for well-educated women compared to men with low education. We tested this by including only the two inequality treatments and an interaction term for all four dependent variables. The results show no significant interaction terms, the closest being the result for useful2 $(p=0.077)$. Hence, we assume that the two treatments are independent of each other.
} 


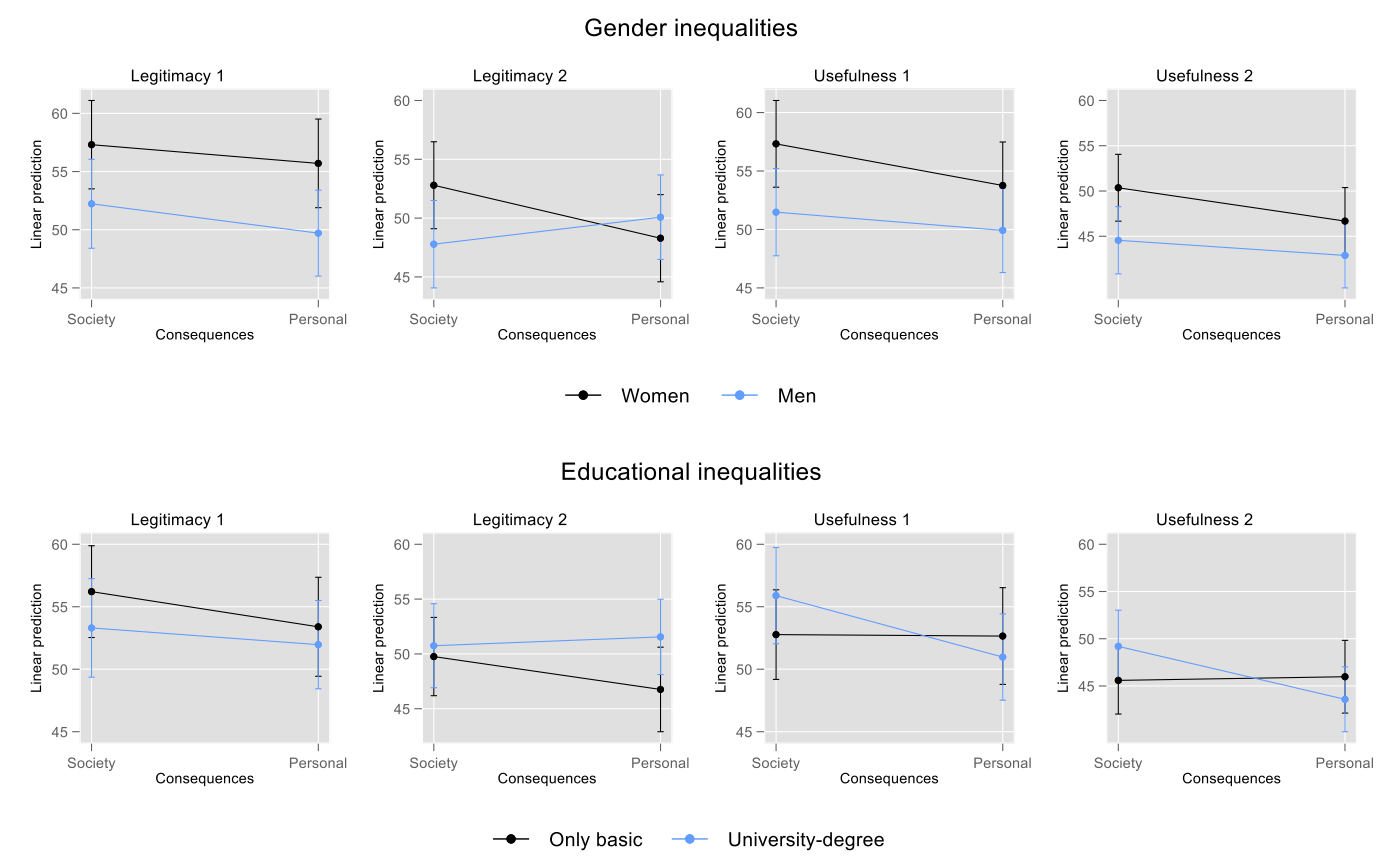

Note: Results represent differences in conditional mean scores depending on issue consequences on scales $0-100$ with $95 \%$ confidence intervals

There are also few relevant differences across issue consequences regardless of measure and type of inequality. The only minor exception is the interaction effect for gender differences, where the differences are fairly pronounced, since legitimacy is higher when women are overrepresented and the issue consequences are societal, which is reversed when consequences are personal. Nevertheless, the differences are even here under all circumstances non-significant although the interaction term approaches significance $(F(1$, $824)=3.28, p=.071)$. Furthermore, even this small piece of evidence of substantial differences contradicts our $\mathrm{H} 5$ that differences are smaller when consequences concern society at large. This shows that effects are rather similar across issue consequences.

So far, our main finding is the pronounced differences in the effects of participatory inequalities depending on whether they are based on gender or educational differences, which are consistent across type of participatory process and issue consequences. While we did not pre-register any hypotheses on this, there are reasons to believe that disadvantaged 
groups put greater emphasis on inequalities (Banducci, Donovan and Karp, 2004; Clayton, O'Brien and Piscopo, 2019). We therefore in Table 3 explore whether there are substantial differences in effects across gender and level of education of the respondents.

Table 3. Differences in mean scores across gender and level of education of respondents

\begin{tabular}{|c|c|c|c|c|c|c|c|c|c|c|}
\hline \multirow{3}{*}{$\begin{array}{l}\text { Treatment: } \\
\text { Group over- } \\
\text { represented }\end{array}$} & \multicolumn{4}{|c|}{ Mean (SE) } & \multirow{3}{*}{$\begin{array}{c}\text { P } \\
\text { Respondent } \\
\text { gender \# } \\
\text { Gender } \\
\text { treatment }\end{array}$} & \multicolumn{4}{|c|}{ Mean (SE) } & \multirow{3}{*}{$\begin{array}{c}\text { P } \\
\text { Responden } \\
\text { education } \\
\text { Education } \\
\text { treatment }\end{array}$} \\
\hline & \multicolumn{2}{|c|}{ Male respondents } & \multicolumn{2}{|c|}{$\begin{array}{l}\text { Female } \\
\text { respondents }\end{array}$} & & \multicolumn{2}{|c|}{$\begin{array}{l}\text { Respondents w high } \\
\text { education }\end{array}$} & \multicolumn{2}{|c|}{$\begin{array}{l}\text { Respondents w low } \\
\text { education }\end{array}$} & \\
\hline & Men & Women & Men & Women & & $\begin{array}{c}\text { High } \\
\text { educated }\end{array}$ & $\begin{array}{l}\text { Low } \\
\text { educated }\end{array}$ & $\begin{array}{c}\text { High } \\
\text { educated }\end{array}$ & $\begin{array}{l}\text { Low } \\
\text { educated }\end{array}$ & \\
\hline Legit1 & 60.8 (1.9) & $55.9(1.9)$ & $42.4(1.8)$ & $57.0(1.9)$ & $<.001$ & $51.1(2.2)$ & $52.3(2.0)$ & $52.3(1.8)$ & $57.5(1.7)$ & 0.135 \\
\hline Legit2 & $53.3(1.8)$ & $51.4(1.9)$ & $45.4(1.8)$ & $49.7(1.9)$ & 0.101 & $45.3(1.9)$ & $43.0(2.1)$ & $55.4(1.7)$ & $52.1(1.7)$ & 0.784 \\
\hline Useful1 & $55.4(1.9)$ & $55.5(1.9)$ & $46.1(1.8)$ & $55.4(1.9)$ & 0.012 & $51.2(2.0)$ & $48.2(2.1)$ & $54.8(1.7)$ & $55.4(1.7)$ & 0.338 \\
\hline Useful2 & $50.7(1.8)$ & $48.7(1.9)$ & $38.0(1.8)$ & $48.5(1.9)$ & $<.001$ & $44.7(2.0)$ & $42.9(2.1)$ & $47.7(1.7)$ & $48.2(1.7)$ & 0.551 \\
\hline
\end{tabular}

The analyses reveal that there are consistent differences in effects of gender inequalities between men and women. There is little difference in mean scores when women are overrepresented between male and female respondents. But when men form the majority, women see procedures as less legitimate, whereas men are more accepting or even approving of this situation across all four measures. For educational inequalities, we again do not discover a similar unambiguous result, since there are no consistent differences between respondents depending on their own educational attainment. These results again show that there are important differences in how people react to inequalities, even among the affected groups.

\section{Robustness tests}

We performed several tests to ensure that our results are robust. First, we as noted above tested that the results were not model specific by testing ANOVA models where we only included direct effects and models where we only included the interaction terms of substantial interest. This way we can ascertain that any non-significant results are not due to 
over-loaded models. The results are included in Appendix 4 and show that the results are substantially similar since it is still only the direct effects of gender inequalities that are significant. Consequently, we are confident that our results are not driven by model specification.

We also included attention checks in study 2 to see whether missing effects could be due to non-attentive respondents. We asked four multiple choice questions asking respondents what they were shown for each of the four treatments. We included three possible answers, two of which were incorrect, and a 'don't know' option to reduce the number of respondents who guessed the correct answer without remembering. The results reported in Appendix 5 show that only about $48 \%$ of respondents could recall the nature of the consequences and $55 \%$ what type of participatory process was shown. This can indicate that these treatments were not sufficiently strong, which also explain why they did not have the expected moderating effect. However, it may also entail that these aspects are not seen as particularly relevant by respondents, who therefore quickly forgot the correct answers.

This latter interpretation is substantiated by the fact that more respondents were able to answer correctly when it came to the two types of inequality, where about $70 \%$ answered correctly on each of these. Furthermore, if we restrict analyses to those who answered correctly, we get similar substantial results, i.e., the direct effects of gender inequalities are significant for three of the four measures while none of the interaction terms reach significance. There is some evidence that educational inequalities play more of a role for Legit2, but the result suggest that the level of legitimacy is higher when those with high education are overrepresented and thus still contradict our hypotheses ( $M=43.1$ when people with low education are in majority compared to $M=47.6$ when the highly educated form the majority). Hence, we can rule out that our results are not driven by the attention level of the respondents. 


\section{Discussion and conclusions}

Our results have several important implications for the link between participatory inequalities and decision-making legitimacy.

First, we can confirm our first hypothesis since our results show that people consider participatory equality to be essential for democracy. While previous studies also show equality to be a valued ideal (Prothro and Grigg, 1960; Howarth et al., 2019), this could not be taken for granted considering the rise of stealth democracy (Hibbing and Theiss-Morse, 2002; Bengtsson and Mattila, 2009; VanderMolen, 2017; Fernández-Martínez and Font, 2018). Furthermore, we show that this holds true even when people get the chance to covertly disregard equality as a key democratic principle. We can therefore discard any concern that participatory equality is mainly valued due to social desirability bias. The worries over increasing participatory inequalities as a result seem warranted (Verba, Schlozman and Brady, 1995; Dalton, 2017; Clayton, O’Brien and Piscopo, 2019).

However, our results also show that all participatory inequalities are not equal. While we set out to examine differences in how participatory inequalities affect input and output legitimacy, our results show that the main differences exist between different types of inequalities. We found a positive effect on legitimacy beliefs when women formed the majority, which was particularly strong among female respondents. This was in line with our expectations for $\mathrm{H} 2 \mathrm{a}$, and shows that it is beneficial for legitimacy when women form the majority while men forming the majority undermines legitimacy (Young, 2000; Clayton, O'Brien and Piscopo, 2019). This is in line with the many studies showing that the descriptive representation of the women is important for decision-making legitimacy, in particular among women (Rosenthal, 1995; Sanbonmatsu, 2003; Atkeson and Carrillo, 2007; Espírito-Santo, 2016). Contrary to our H3a, output legitimacy in the form of the perceived usefulness of the output was also boosted when women formed the majority rather than men. Hence, women 
are considered to be as capable of delivering useful input, which is testament to the strong norms of gender equality in Finland (Inglehart and Norris, 2003).

Contrary to our initial expectations, we found no similar results for educational inequalities. Differences in perceptions of legitimacy were scarce regardless of educational composition, which contradicted both $\mathrm{H} 3 \mathrm{~b}$ and $\mathrm{H} 4 \mathrm{~b}$. This is interesting considering the literature arguing that educational differences are imperative for understanding differences in participation (Verba, Schlozman and Brady, 1995; Dalton, 2017), but is in line with the findings of Mayne and Peters (2022). This shows that, even if educational differences have become increasingly salient (Stubager, 2010; Kriesi et al., 2012), it does not hurt decision-making legitimacy when people with high education form the majority. Furthermore, there are few worries over the output quality of participation when those with little education are in majority (Verba, 2003).

Since several studies show that the highly educated are more politically active, it is encouraging for those worried about democratic legitimacy that this does not necessarily have detrimental effects on decision-making legitimacy. More importantly for the present purposes, this finding also calls attention to the very different implications of different types of inequalities. Whereas gender matters in a consistent manner, educational attainment does not play a similar role, not even for the perceived usefulness of the outcome of the process. While this result was not our principal concern from the outset, this shows that it is important to specify exactly what participatory inequalities are in play when discussing the potential implications for how citizens evaluate the legitimacy of participatory processes.

We may at this point only speculate as to why these differences occur. For one, while both types of inequalities have received considerable attention in academic literature, gender inequalities are arguable more visible in popular discourse and media, which help explain the differences. Furthermore, gender roles have an inherently cultural component that is not predetermined, gender roles are for most people fixed at birth and remain stable throughout the 
life course. This means there is little free choice involved in selecting your gender and discrimination or exclusion based on this is therefore less acceptable. Education, on the other hand, is in principle available to everyone, not least in a Finnish welfare state with free education to all citizens. This type of inequality might be more acceptable since it is in principle possible for all individuals to become one of the well-educated. It is entirely possible that other results would be found outside of Finland with an education system that provides high levels of educational equity (Ustun \& Eryilmaz, 2018).

It should also be noted that these differences were stable across type of participation and the consequences of the issue since we found no systematic evidence that these moderated the effects of either type of inequality. This seems to suggest that such characteristics matter less than what is often assumed (Clayton, O'Brien and Piscopo, 2019; Solodoch, 2020; Werner and Marien, 2020; el-Wakil and Strebel, 2022). However, it should here be noted that there are other relevant aspects that matter more than those we here examined, so there is still a need to examine factors that potentially moderate the impact of inequalities.

Other limitations to our studies also exist. As mentioned, the case of Finland constitutes a suitable case due to the strong culture of equality. However, it is necessary to explore whether similar results can be obtained elsewhere, preferably in a comparative manner that makes it possible to assess the impact of contextual traits such as culture and institutional factors, which can affect the impact of inequalities (Cooray and Potrafke, 2011; Li, Zuckerman and Diener, 2021).

Our exploratory findings suggest that the results differ across groups in society since women were clearly more likely to react when women form a minority (Rosenthal, 1995; Clayton, O'Brien and Piscopo, 2019). Again, no differences across the educational attainment of respondents exist. More research is here needed to establish what groups react to what types of under-representation, and to examine the causal mechanisms that can help explain when 
participatory inequalities have detrimental effects on legitimacy. In connection to this, it is worth highlighting that other types of inequalities might have entirely different effects. A particularly topical aspect here concerns how the over- or underrepresentation of ethnic and religious immigrants and minorities affect attitudes to democratic legitimacy, since this is arguable one of the developments presently putting democracy under strain.

These caveats notwithstanding, our results clearly show that it is important to further investigate differences in how participatory inequalities affect democratic legitimacy. 


\section{Reference list}

Afsahi, A. (2022) 'Gender Difference in Willingness and Capacity for Deliberation', Social Politics: International Studies in Gender, State \& Society, 28(4), pp. 1046-1072. doi:10.1093/sp/jxaa003.

Ahlquist, J.S. (2018) 'List Experiment Design, Non-Strategic Respondent Error, and Item Count Technique Estimators', Political Analysis, 26(1), pp. 34-53. doi:10.1017/pan.2017.31.

Altman, D. (2011) Direct democracy worldwide. Cambridge: Cambridge University Press.

Andersen, R. and Fetner, T. (2008) 'Economic Inequality and Intolerance: Attitudes toward Homosexuality in 35 Democracies', American Journal of Political Science, 52(4), pp. 942-958.

Anderson, C.J. and Singer, M.M. (2008) 'The Sensitive Left and the Impervious Right: Multilevel Models and the Politics of Inequality, Ideology, and Legitimacy in Europe', Comparative Political Studies, 41(4-5), pp. 564-599.

Armingeon, K. and Schädel, L. (2015) 'Social Inequality in Political Participation: The Dark Sides of Individualisation', West European Politics, 38(1), pp. 1-27. doi:10.1080/01402382.2014.929341.

Arnesen, S. (2017) 'Legitimacy from Decision-Making Influence and Outcome Favourability: Results from General Population Survey Experiments', Political Studies, 65(1_suppl). doi:10.1177/0032321716667956.

Arnesen, S., Duell, D. and Johannesson, M.P. (2019) ‘Do citizens make inferences from political candidate characteristics when aiming for substantive representation?', Electoral Studies, 57, pp. 46-60. doi:10.1016/j.electstud.2018.10.005.

Arnesen, S. and Peters, Y. (2018) 'The Legitimacy of Representation: How Descriptive, Formal, and Responsiveness Representation Affect the Acceptability of Political Decisions', Comparative Political Studies, 51(7), pp. 868-899. doi:10.1177/0010414017720702.

Atkeson, L.R. and Carrillo, N. (2007) 'More is Better: The Influence of Collective Female Descriptive Representation on External Efficacy', Politics \& Gender, 3(01). doi:10.1017/S1743923X0707002X.

Banducci, S.A., Donovan, T. and Karp, J.A. (2004) 'Minority Representation, Empowerment, and Participation', The Journal of Politics, 66(2), pp. 534-556. doi:10.1111/j.14682508.2004.00163.x.

Beauvais, E. (2020) 'The Gender Gap in Political Discussion Group Attendance', Politics \& Gender, 16(2), pp. 315-338. doi:10.1017/S1743923X18000892.

Beauvais, E. (2021) 'Discursive Inequity and the Internal Exclusion of Women Speakers', Political Research Quarterly, 74(1), pp. 103-116. doi:10.1177/1065912919870605.

Bengtsson, Å. and Christensen, H.S. (2016) 'Ideals and Actions: Do Citizens' Patterns of Political Participation Correspond to their Conceptions of Democracy?', Government and Opposition, 51(02), pp. 234-260. doi:10.1017/gov.2014.29. 
Bengtsson, Å. and Mattila, M. (2009) 'Direct Democracy and its Critics: Support for Direct Democracy and "Stealth" Democracy in Finland', West European Politics, 32(5), pp. 10311048. doi:10.1080/01402380903065256.

Blair, G. and Imai, K. (2012) 'Statistical Analysis of List Experiments', Political Analysis, 20(1), pp. 47-77. doi:10.1093/pan/mpr048.

Blair, G., Imai, K. and Lyall, J. (2014) 'Comparing and Combining List and Endorsement Experiments: Evidence from Afghanistan', American Journal of Political Science, 58(4), pp. 1043-1063. doi:10.1111/ajps.12086.

Bolzendahl, C. and Coffe, H. (2013) 'Are "Good" Citizens "Good" Participants? Testing Citizenship Norms and Political Participation across 25 Nations', Political Studies, 61(SUPPL.1), pp. 63-83. doi:10.1111/1467-9248.12010.

Bowles, S., Gintis, H. and Groves, M.O. (2005) Unequal Chances: Family Background and Economic Success. Princeton University Press.

Burns, N. (2007) 'Gender in the Aggregate, Gender in the Individual, Gender and Political Action', Politics \& Gender, 3(1), pp. 104-124. doi:10.1017/S1743923X07221014.

Carnes, N. and Sadin, M.L. (2015) 'The "Mill Worker's Son" Heuristic: How Voters Perceive Politicians from Working-Class Families-and How They Really Behave in Office', The Journal of Politics, 77(1), pp. 285-298. doi:10.1086/678530.

Chong, D., Citrin, J. and Conley, P. (2001) 'When Self-Interest Matters', Political Psychology, 22(3), pp. 541-570. doi:10.1111/0162-895X.00253.

Christensen, H.S., Himmelroos, S. and Setälä, M. (2020) 'A Matter of Life or Death: A Survey Experiment on the Perceived Legitimacy of Political Decision-Making on Euthanasia', Parliamentary Affairs, 73(3), pp. 6276-50. doi:10.1093/pa/gsz014.

Clayton, A., O'Brien, D.Z. and Piscopo, J.M. (2019) 'All Male Panels? Representation and Democratic Legitimacy', American Journal of Political Science, 63(1), pp. 113-129.

Coffé, H. and Bolzendahl, C. (2010) 'Same Game, Different Rules? Gender Differences in Political Participation', Sex Roles, 62(5-6), pp. 318-333. doi:10.1007/s11199-009-9729-y.

Cooray, A. and Potrafke, N. (2011) 'Gender inequality in education: Political institutions or culture and religion?', European Journal of Political Economy, 27(2), pp. 268-280. doi:10.1016/j.ejpoleco.2010.08.004.

Dahl, R.A. (1989) Democracy and Its Critics. Yale University Press.

Dahl, R.A. (1998) On Democracy. Yale University Press.

Dalton, R.J. (2017) The participation gap: Social status and political inequality. Oxford: Oxford University Press.

Däubler, T., Quoß, F. and Rudolph, L. (2021) 'Do Citizens use Sociodemographic Characteristics as Cues to Infer Candidate Issue Positions?', Swiss Political Science Review, Online first. doi:10.1111/spsr.12493. 
Dolan, K. (2010) 'The Impact of Gender Stereotyped Evaluations on Support for Women Candidates', Political Behavior, 32(1), pp. 69-88. doi:10.1007/s11109-009-9090-4.

Dolan, K. and Sanbonmatsu, K. (2009) 'Gender Stereotypes and Attitudes Toward Gender Balance in Government', American Politics Research, 37(3), pp. 409-428. doi:10.1177/1532673×08322109.

Eckstein, H. (1975) 'Case study and theory in political science', in Greenstein, F. and Polsby, N. (eds) Handbook of Political Science. Reading, MA: Addison-Wesley, pp. 79-138.

Esaiasson, P., Gilljam, M. and Persson, M. (2017) 'Responsiveness Beyond Policy Satisfaction: Does It Matter to Citizens?', Comparative Political Studies, 50(6), pp. 739-765. doi:10.1177/0010414015626445.

Espírito-Santo, A. (2016) 'Citizens' attitudes towards descriptive representation: The case of women in Portugal', European Journal of Women's Studies, 23(1), pp. 43-59. doi:10.1177/1350506814568036.

Faul, F. et al. (2009) 'Statistical power analyses using G*Power 3.1: Tests for correlation and regression analyses', Behavior Research Methods, 41(4), pp. 1149-1160. doi:10.3758/BRM.41.4.1149.

Fernández-Martínez, J.L. and Font, J. (2018) 'The devil is in the detail: What do citizens mean when they support stealth or participatory democracy?', Politics, 38(4), pp. 458-479. doi:10.1177/0263395717741799.

Ferrín, M. and Kriesi, H. (eds) (2016) How Europeans View and Evaluate Democracy. Oxford, New York: Oxford University Press (Comparative Politics).

Fung, A. (2003) 'Survey Article: Recipes for Public Spheres: Eight Institutional Design Choices and Their Consequences', Journal of Political Philosophy, 11(3), pp. 338-367. doi:10.1111/1467-9760.00181.

Gherghina, S. and Geissel, B. (2017) 'Linking Democratic Preferences and Political Participation: Evidence from Germany', Political Studies, 65(1_suppl), pp. 003232171667222 003232171667222 . doi:10.1177/0032321716672224.

Gilens, M. (2005) 'Inequality and Democratic Responsiveness', The Public Opinion Quarterly, 69(5), pp. 778-796.

Gilley, B. (2006) 'The meaning and measure of state legitimacy: Results for 72 countries', European Journal of Political Research, 45(3), pp. 499-525. doi:10.1111/j.14756765.2006.00307.x.

Glynn, A.N. (2013) 'What Can We Learn with Statistical Truth Serum?: Design and Analysis of the List Experiment', Public Opinion Quarterly, 77(S1), pp. 159-172. doi:10.1093/poq/nfs070.

Grasso, M. and Smith, K. (2022) 'Gender inequalities in political participation and political engagement among young people in Europe: Are young women less politically engaged than young men?', Politics, 42(1), pp. 39-57. doi:10.1177/02633957211028813.

Grönlund, K., Bächtiger, A. and Setälä, M. (eds) (2014) Deliberative Mini-Publics: Involving Citizens in the Democratic Process. Colchester: ECPR Press. 
Hainmueller, J., Hangartner, D. and Yamamoto, T. (2015) 'Validating vignette and conjoint survey experiments against real-world behavior', Proceedings of the National Academy of Sciences, 112(8), pp. 2395-2400. doi:10.1073/pnas.1416587112.

Haselswerdt, J. (2020) 'Carving Out: Isolating the True Effect of Self-Interest on Policy Attitudes', American Political Science Review, 114(4), pp. 1103-1116. doi:10.1017/S0003055420000465.

Hibbing, J.R. and Theiss-Morse, E. (2002) Stealth Democracy. Cambridge: Cambridge University Press. Available at: http://ebooks.cambridge.org/ref/id/CBO9780511613722.

Howarth, D. et al. (2019) 'What do the British public think of inequality in health, wealth, and power?', Social Science \& Medicine, 222, pp. 198-206. doi:10.1016/j.socscimed.2019.01.006.

Huttunen, J. and Christensen, H.S. (2020) 'Engaging the Millennials: The Citizens' Initiative in Finland', YOUNG, 28(2), pp. 175-198. doi:10.1177/1103308819853055.

Inglehart, R. and Norris, P. (2003) Rising Tide: Gender Equality and Cultural Change Around the World. Cambridge University Press.

Jäske, M. (2017) "'Soft" forms of direct democracy: Explaining the occurrence of referendum motions and advisory referendums in Finnish local government', Swiss Political Science Review, 23(1), pp. 50-76. doi:10.1111/spsr.12238.

Karpowitz, C.F., Mendelberg, T. and Shaker, L. (2012) 'Gender Inequality in Deliberative Participation', American Political Science Review, 106(03), pp. 533-547. doi:10.1017/\$0003055412000329.

Karpowitz, C.F., Raphael, C. and Hammond, A.S. (2009) 'Deliberative Democracy and Inequality: Two Cheers for Enclave Deliberation among the Disempowered', Politics \& Society, 37(4), pp. 576-615. doi:10.1177/0032329209349226.

Karvonen, L. (2014) Parties, Governments and Voters in Finland: Politics Under Fundamental Societal Transformation. ECPR Press.

Kinder, D.R. and Kiewiet, D.R. (1981) 'Sociotropic Politics: The American Case', British Journal of Political Science, 11(2), pp. 129-161. doi:10.1017/S0007123400002544.

Kramon, E. and Weghorst, K. (2019) '(Mis)Measuring Sensitive Attitudes with the List Experiment: Solutions to List Experiment Breakdown in Kenya', Public Opinion Quarterly, 83(S1), pp. 236-263. doi:10.1093/poq/nfz009.

Kriesi, H. et al. (2012) Political Conflict in Western Europe. Cambridge University Press.

Krumpal, I. (2013) 'Determinants of social desirability bias in sensitive surveys: a literature review', Quality \& Quantity, 47(4), pp. 2025-2047. doi:10.1007/s11135-011-9640-9.

LeDuc, L. (2015) 'Referendums and deliberative democracy', Electoral Studies, 38, pp. 139148. doi:10.1016/j.electstud.2015.02.007.

Li, C., Zuckerman, M. and Diener, E. (2021) 'Culture Moderates the Relation Between Gender Inequality and Well-Being', Psychological Science, 32(6), pp. 823-835. doi:10.1177/0956797620972492. 
Mayne, Q. and Peters, Y. (2022) 'Where you sit is where you stand: education-based descriptive representation and perceptions of democratic quality', West European Politics, pp. 1-24. doi:10.1080/01402382.2022.2071044.

Mutz, D.C. (2011) Population-based survey experiments. Princeton, New Jersey: Princeton University Press.

Nederhof, A.J. (1985) 'Methods of coping with social desirability bias: A review', European Journal of Social Psychology, 15(3), pp. 263-280. doi:10.1002/ejsp.2420150303.

Pitkin, H.F. (1967) The Concept of Representation. University of California Press.

Prothro, J.W. and Grigg, C.M. (1960) 'Fundamental Principles of Democracy: Bases of Agreement and Disagreement', The Journal of Politics, 22(2), pp. 276-294. doi:10.2307/2127359.

Qvortrup, M. (2013) Direct democracy: a comparative study of the theory and practice of government by the people. Manchester: Manchester University Press.

Rashotte, L.S. and Webster, M. (2005) 'Gender status beliefs', Social Science Research, 34(3), pp. 618-633. doi:10.1016/j.ssresearch.2004.05.004.

Riambau, G. and Ostwald, K. (2021) 'Placebo statements in list experiments: Evidence from a face-to-face survey in Singapore', Political Science Research and Methods, 9(1), pp. 172-179. doi:10.1017/psrm.2020.18.

Rosenthal, C.S. (1995) 'The Role of Gender in Descriptive Representation', Political Research Quarterly, 48(3), pp. 599-611. doi:10.1177/106591299504800307.

Sanbonmatsu, K. (2003) 'Gender-Related Political Knowledge and the Descriptive Representation of Women', Political Behavior, 25(4), pp. 367-388. doi:10.1023/B:POBE.0000004063.83917.2d.

Sandel, M.J. (2021) Tyranny of merit: what's become of the common good? London: Penguin Books.

Scharpf, F. (1999) Governing in Europe: Effective and Democratic? Oxford University Press.

Schlozman, K.L., Burns, N. and Verba, S. (1994) 'Gender and the Pathways to Participation: The Role of Resources', The Journal of Politics, 56(4), pp. 963-990. doi:10.2307/2132069.

Schmidt, V.A. (2013) 'Democracy and Legitimacy in the European Union Revisited: Input, Output and "Throughput", Political Studies, 61(1), pp. 2-22. doi:10.1111/j.14679248.2012.00962.x.

Silagadze, N. et al. (2022) 'Perceptions of Inequality and Political Participation: The Moderating Role of Ideology', Political Studies Review, p. 14789299221082036. doi:10.1177/14789299221082037.

Silagadze, N. and Gherghina, S. (2018) 'When who and how matter: explaining the success of referendums in Europe', Comparative European Politics, 16(5), pp. 905-922. doi:10.1057/s41295-017-0107-9. 
Smith, G. (2009) Democratic Innovations: designing institutions for citizen participation. Cambridge: Cambridge University Press.

Solodoch, O. (2020) 'Do Sociotropic Concerns Mask Prejudice? Experimental Evidence on the Sources of Public Opposition to Immigration', Political Studies. doi:10.1177/0032321720946163.

Solt, F. (2008) 'Economic Inequality and Democratic Political Engagement', American Journal of Political Science, 52(1), pp. 48-60.

Stubager, R. (2010) 'The development of the education cleavage: Denmark as a critical case', West European Politics, 33(3), pp. 505-533. doi:10.1080/01402381003654544.

Tyler, T.R., Feldman, S. and Rasinski, K. (2006) 'Psychological Perspectives on Legitimacy and Legitimation', Annual Review of Psychology, 57(1), pp. 375-400. doi:10.1146/annurev.psych.57.102904.190038.

VanderMolen, K. (2017) 'Stealth Democracy Revisited: Reconsidering Preferences for Less Visible Government', Political Research Quarterly, 70(3), pp. 687-698. doi:10.1177/1065912917712478.

Verba, S. (2003) 'Would the Dream of Political Equality Turn out to Be a Nightmare?', Perspectives on Politics, 1(4), pp. 663-679.

Verba, Sidney., Schlozman, K.L. and Brady, H.E. (1995) Voice and equality : civic voluntarism in American politics. Cambridge, MA: Harvard University Press.

el-Wakil, A. and Strebel, M.A. (2022) 'Participatory processes and their outcomes: comparing assembly and popular vote decisions', European Political Science Review, pp. 1-18. doi:10.1017/S1755773922000157.

Weatherford, M.S. (1992) 'Measuring Political Legitimacy.', American Political Science Review, 86(01), pp. 149-166. doi:10.2307/1964021.

Werner, H. and Marien, S. (2020) 'Process vs. Outcome? How to Evaluate the Effects of Participatory Processes on Legitimacy Perceptions', British Journal of Political Science, First view, pp. 1-8. doi:10.1017/S0007123420000459.

Young, I.M. (2000) Inclusion and Democracy. Oxford: Oxford University Press. 


\section{Online appendix}

\section{Appendix 1: Characteristics of respondents compared to Finnish population}

Table A1 shows that characteristics of the respondents in both studies when it comes to age, gender and place of living.

Table A1. Characteristics of respondents and target population

\begin{tabular}{lccc}
\hline (\%) & STUDY $\mathbf{1}(\mathbf{n}=\mathbf{3 2 4})$ & Study $\mathbf{2}(\mathbf{n}=\mathbf{8 4 0})$ & $\begin{array}{c}\text { Finnish population } \\
\text { Excluding Åland islands) }\end{array}$ \\
\hline Gender & 49.4 & 49.7 & 50.0 \\
Male & 50.6 & 50.3 & 50.0 \\
Female & 100.0 & 100.0 & 100.0 \\
& & & \\
Age group & 22.2 & 23.0 & 23.0 \\
$\mathbf{1 8 - 2 9}$ & 19.1 & 19.1 & 19.0 \\
$\mathbf{3 0 - 3 9}$ & 17.9 & 18.0 & 18.0 \\
$\mathbf{4 0 - 4 9}$ & 20.4 & 19.9 & 20.0 \\
$\mathbf{5 0 - 5 9}$ & 20.4 & 20.0 & 20.0 \\
$\mathbf{6 0 -}$ & 100.0 & 100.0 & 100.0 \\
& & & 24.0 \\
Region of living & 24.4 & 24.3 & 21.0 \\
North \& East Finland & 20.7 & 20.8 & 30.0 \\
South Finland & 30.3 & 29.9 & 25.0 \\
Helsinki-Uusimaa & 24.7 & 25.0 & 100.0 \\
West Finland & 100.0 & 100.0 & \\
& &
\end{tabular}

Since the distribution of respondents in both studies resemble the Finnish population, we do not apply weighting when performing the analyses. 


\section{Appendix 2: Deviations from the pre-registration}

\section{Study 1}

The preregistration concerning hypotheses, data collection, variables and analyses can be found at:

\section{https://osf.io/4nbcz/?view only=12857ff47f1342febcd8c02de07d4f3a}

In the following, we outline the deviations from the pre-registration that occurred during writing up the results:

- The hypothesis has been slightly altered from the pre-registration to include "participatory", since we want to emphasize that we are here interested in this particular type of (in)equality. The content remains identical.

\section{STUDY 2}

This study was preregistered for hypotheses, data collection, variables and analyses at: https://osf.io/riqux/?view only=03c7b3039ae14b78a5c1fb533537f9c0

In the following, we note the deviations from the pre-registration that occurred during the process:

- The numbering of the hypotheses has been altered since the two studies are reported in the same paper. $\mathrm{H} 1 \mathrm{a}$ and $\mathrm{Hb}$ in the pre-registration are here referred to as $\mathrm{H} 2 \mathrm{a}$ and $\mathrm{H} 2 \mathrm{~b}, \mathrm{H} 2 \mathrm{a}$ and $\mathrm{H} 2 \mathrm{~b}$ in the pre-registration are here referred to as $\mathrm{H} 3 \mathrm{a}$ and $\mathrm{H} 3 \mathrm{~b}$, while $\mathrm{H} 3$ and $\mathrm{H} 4$ in the pre-registration are here referred to as $\mathrm{H} 4$ and $\mathrm{H} 5$. The content is identical.

- We have slightly rephrased $\mathrm{H} 3 \mathrm{a}$ and $\mathrm{H} 3 \mathrm{~b}$ to reflect that we consider usefulness a form of output legitimacy. The intention remain identical.

- We have rephrased $\mathrm{H} 4$ and $\mathrm{H} 5$ to clarify that we expect differences in both subjective legitimacy and perceived usefulness to differ depending on type of participatory process and issue consequences. The intention remain identical. 
- We now include analyses on differences across respondents for the results. No hypotheses were pre-registered for these, but it was mentioned that exploratory analyses would be performed. 


\section{Appendix 3: Distribution of respondents in list experiments}

We in Table A2 show the distribution of answers in both list experiments included in study 1.

Table A2. Distribution of answers in list experiments

\begin{tabular}{ccccccccc}
\hline & \multicolumn{3}{c}{$\begin{array}{c}\text { List experiment 1 (LE1) } \\
\text { Control }\end{array}$} & $\begin{array}{c}\text { Treatment } \\
\text { Vrequency }\end{array}$ & \% & Frequency & \% & \multicolumn{2}{c}{$\begin{array}{c}\text { List experiment 2 (LE2) } \\
\text { Control }\end{array}$} & \multicolumn{2}{c}{$\begin{array}{c}\text { Treatment } \\
\text { Frequency }\end{array}$} & \% & Frequency & \% \\
\hline $\mathbf{0}$ & 7 & 4.3 & 2 & 1.3 & 3 & 1.8 & 1 & 0.6 \\
$\mathbf{1}$ & 5 & 3.1 & 1 & 0.6 & 10 & 6.1 & 10 & 6.3 \\
$\mathbf{2}$ & 10 & 6.1 & 4 & 2.5 & 34 & 20.7 & 21 & 13.1 \\
$\mathbf{3}$ & 93 & 56.7 & 22 & 13.8 & 81 & 49.4 & 45 & 28.1 \\
$\mathbf{4}$ & 35 & 21.3 & 77 & 48.1 & 24 & 14.6 & 65 & 40.6 \\
$\mathbf{5}$ & 14 & 8.5 & 54 & 33.8 & 12 & 7.3 & 18 & 11.3 \\
\hline Total & 164 & & 160 & & 164 & & 160 & \\
\hline
\end{tabular}

For both experiments, the modal values are the expected 3 in the control group and 4 in the treatment group. However, there is quite a few respondents at the extremes. It is in particular worth noting that in LE1 a third of the respondents in the treatment group select 5 as their answer. We are unable to tell whether this is because of strategic or non-strategic reasons; i.e. whether respondents wanted to conceal their true motivations or misunderstood the task at hand. 
Appendix 4: Mean scores and ANOVA models for Study 2

First, we in table A3 report the mean scores for the four treatments and all 16 combinations

of them for the four dependent variables.

Table A3. Mean scores for main effects and combinations

\begin{tabular}{|c|c|c|c|c|c|c|c|c|c|c|c|c|c|c|c|}
\hline \multirow[b]{2}{*}{ Main effects } & \multicolumn{4}{|c|}{ Leg1 } & \multicolumn{4}{|c|}{ Leg2 } & \multicolumn{4}{|c|}{ Useful1 } & \multicolumn{3}{|c|}{ Useful2 } \\
\hline & Mean & SE & $\mathbf{9 5} \%$ & ${ }_{0} \mathrm{CI}$ & Mean & SE & $95 \%$ & ${ }_{0} \mathrm{CI}$ & Mean & SE & $95 \%$ & $\% \mathrm{CI}$ & Mean & SE & $95 \% \mathrm{CI}$ \\
\hline Women overrepresented & 56.39 & 1.30 & 53.84 & 58.93 & 50.77 & 1.27 & 48.27 & 53.27 & 55.59 & 1.25 & 53.14 & 58.04 & 48.73 & 1.25 & 46.2851 .18 \\
\hline Men overrepresented & 51.41 & 1.37 & 48.72 & 54.09 & 48.87 & 1.31 & 46.30 & 51.45 & 50.50 & 1.36 & 47.84 & 53.17 & 43.85 & 1.36 & 41.1946 .51 \\
\hline \multicolumn{16}{|l|}{ Education } \\
\hline Low educated overrepresented & 54.79 & 1.41 & 52.03 & 57.54 & 48.22 & 1.33 & 45.61 & 50.83 & 52.46 & 1.36 & 49.79 & 55.14 & 45.80 & 1.34 & 43.1648 .43 \\
\hline High educated overrepresented & 52.94 & 1.28 & 50.43 & 55.44 & 51.32 & 1.26 & 48.85 & 53.79 & 53.50 & 1.26 & 51.03 & 55.98 & 46.67 & 1.28 & 44.1649 .18 \\
\hline \multicolumn{16}{|l|}{ Participatory process } \\
\hline Discussion forum & 52.30 & 1.31 & 49.73 & 54.86 & 50.12 & 1.27 & 47.62 & 52.61 & 53.20 & 1.28 & 50.68 & 55.72 & 46.00 & 1.31 & 43.4248 .57 \\
\hline Referendum & 55.41 & 1.37 & 52.72 & 58.11 & 49.48 & 1.32 & 46.89 & 52.07 & 52.78 & 1.34 & 50.16 & 55.41 & 46.49 & 1.31 & 43.9249 .06 \\
\hline \multicolumn{16}{|l|}{ Issue consequences } \\
\hline Society & 54.99 & 1.32 & 52.39 & 57.58 & 50.12 & 1.36 & 47.45 & 52.79 & 53.93 & 1.33 & 51.32 & 56.54 & 47.43 & 1.33 & 44.8250 .04 \\
\hline Personal & 52.72 & 1.35 & 50.06 & 55.38 & 49.49 & 1.23 & 47.07 & 51.90 & 52.07 & 1.29 & 49.53 & 54.61 & 45.07 & 1.29 & $42.54 \quad 47.60$ \\
\hline \multicolumn{16}{|l|}{ Combinations } \\
\hline $\begin{array}{l}\text { Society\#Discussion forum\#Women\#Only } \\
\text { basic }\end{array}$ & 56.88 & 4.17 & 48.69 & 65.07 & 53.49 & 4.06 & 45.52 & 61.46 & 57.28 & 4.08 & 49.28 & 65.28 & 46.00 & 4.06 & 38.0453 .96 \\
\hline $\begin{array}{l}\text { Society\#Discussion } \\
\text { forum\#Women\#University-degree }\end{array}$ & 54.71 & 3.56 & 47.72 & 61.70 & 51.41 & 3.47 & 44.61 & 58.21 & 56.78 & 3.48 & 49.95 & 63.61 & 53.27 & 3.46 & $46.47 \quad 60.07$ \\
\hline $\begin{array}{l}\text { Society\#Discussion forum\#Men\#Only } \\
\text { basic }\end{array}$ & 52.24 & 3.59 & 45.19 & 59.29 & 47.13 & 3.49 & 40.27 & 53.99 & 46.83 & 3.51 & 39.94 & 53.72 & 43.03 & 3.49 & 36.1849 .89 \\
\hline $\begin{array}{l}\text { Society\#Discussion } \\
\text { forum\#Men\#University-degree }\end{array}$ & 44.62 & 4.22 & 36.33 & 52.91 & 46.03 & 4.11 & 37.97 & 54.09 & 47.64 & 4.12 & 39.55 & 55.74 & 35.33 & 4.10 & 27.2843 .39 \\
\hline Society\#Referendum\#Women\#Only basic & 59.65 & 4.03 & 51.73 & 67.57 & 51.45 & 3.92 & 43.75 & 59.15 & 57.30 & 3.94 & 49.57 & 65.04 & 48.63 & 3.92 & 40.9356 .33 \\
\hline $\begin{array}{l}\text { Society\#Referendum\#Women\#University- } \\
\text { degree }\end{array}$ & 58.11 & 3.72 & 50.80 & 65.42 & 54.94 & 3.62 & 47.83 & 62.05 & 57.96 & 3.64 & 50.82 & 65.10 & 53.28 & 3.62 & 46.1760 .38 \\
\hline Society\#Referendum\#Men\#Only basic & 56.29 & 3.12 & 50.16 & 62.41 & 47.19 & 3.03 & 41.23 & 53.14 & 50.09 & 3.05 & 44.11 & 56.07 & 44.88 & 3.03 & 38.9350 .83 \\
\hline $\begin{array}{l}\text { Society\#Referendum\#Men\#University- } \\
\text { degree }\end{array}$ & 56.18 & 4.44 & 47.47 & 64.90 & 50.88 & 4.32 & 42.40 & 59.35 & 61.47 & 4.34 & 52.96 & 69.98 & 55.47 & 4.31 & $47.00 \quad 63.94$ \\
\hline $\begin{array}{l}\text { Personal\#Discussion forum\#Women\#Only } \\
\text { basic }\end{array}$ & 54.44 & 4.27 & 46.05 & 62.83 & 46.34 & 4.16 & 38.18 & 54.50 & 53.10 & 4.17 & 44.90 & 61.29 & 46.61 & 4.15 & 38.4654 .76 \\
\hline $\begin{array}{l}\text { Personal\#Discussion } \\
\text { forum\#Women\#University-degree }\end{array}$ & 56.16 & 3.45 & 49.39 & 62.93 & 51.32 & 3.35 & 44.74 & 57.90 & 57.60 & 3.37 & 50.99 & 64.21 & 47.78 & 3.35 & 41.2054 .36 \\
\hline $\begin{array}{l}\text { Personal\#Discussion forum\#Men\#Only } \\
\text { basic }\end{array}$ & 54.21 & 3.50 & 47.34 & 61.09 & 49.18 & 3.41 & 42.49 & 55.87 & 55.97 & 3.42 & 49.25 & 62.68 & 50.20 & 3.41 & 43.5156 .88 \\
\hline $\begin{array}{l}\text { Personal\#Discussion } \\
\text { forum\#Men\#University-degree }\end{array}$ & 44.04 & 3.66 & 36.86 & 51.21 & 54.76 & 3.56 & 47.78 & 61.74 & 49.18 & 3.57 & 42.17 & 56.19 & 42.36 & 3.55 & 35.3849 .33 \\
\hline Personal\#Referendum\#Women\#Only basic & 57.49 & 4.38 & 48.89 & 66.09 & 45.30 & 4.26 & 36.93 & 53.66 & 52.15 & 4.28 & 43.75 & 60.55 & 45.10 & 4.26 & 36.7453 .46 \\
\hline $\begin{array}{l}\text { Personal\#Referendum\#Women\#University- } \\
\text { degree }\end{array}$ & 54.65 & 3.37 & 48.04 & 61.26 & 50.00 & 3.28 & 43.57 & 56.43 & 51.97 & 3.29 & 45.51 & 58.43 & 47.18 & 3.27 & 40.7653 .61 \\
\hline Personal\#Referendum\#Men\#Only basic & 47.60 & 3.99 & 39.76 & 55.43 & 46.10 & 3.88 & 38.48 & 53.72 & 49.32 & 3.90 & 41.67 & 56.97 & 41.89 & 3.88 & 34.2849 .51 \\
\hline $\begin{array}{l}\text { Personal\#Referendum\#Men\#University- } \\
\text { degree }\end{array}$ & 53.42 & 3.87 & 45.82 & 61.02 & 50.00 & 3.76 & 42.61 & 57.39 & 45.40 & 3.78 & 37.98 & 52.82 & 37.32 & 3.76 & $29.94 \quad 44.70$ \\
\hline
\end{tabular}


In Table A4, we report results from factorial ANOVA analyses of all four dependent variables and including all possible interactions. These are the results we report in the text.

Table A4. Full factorial ANOVA models

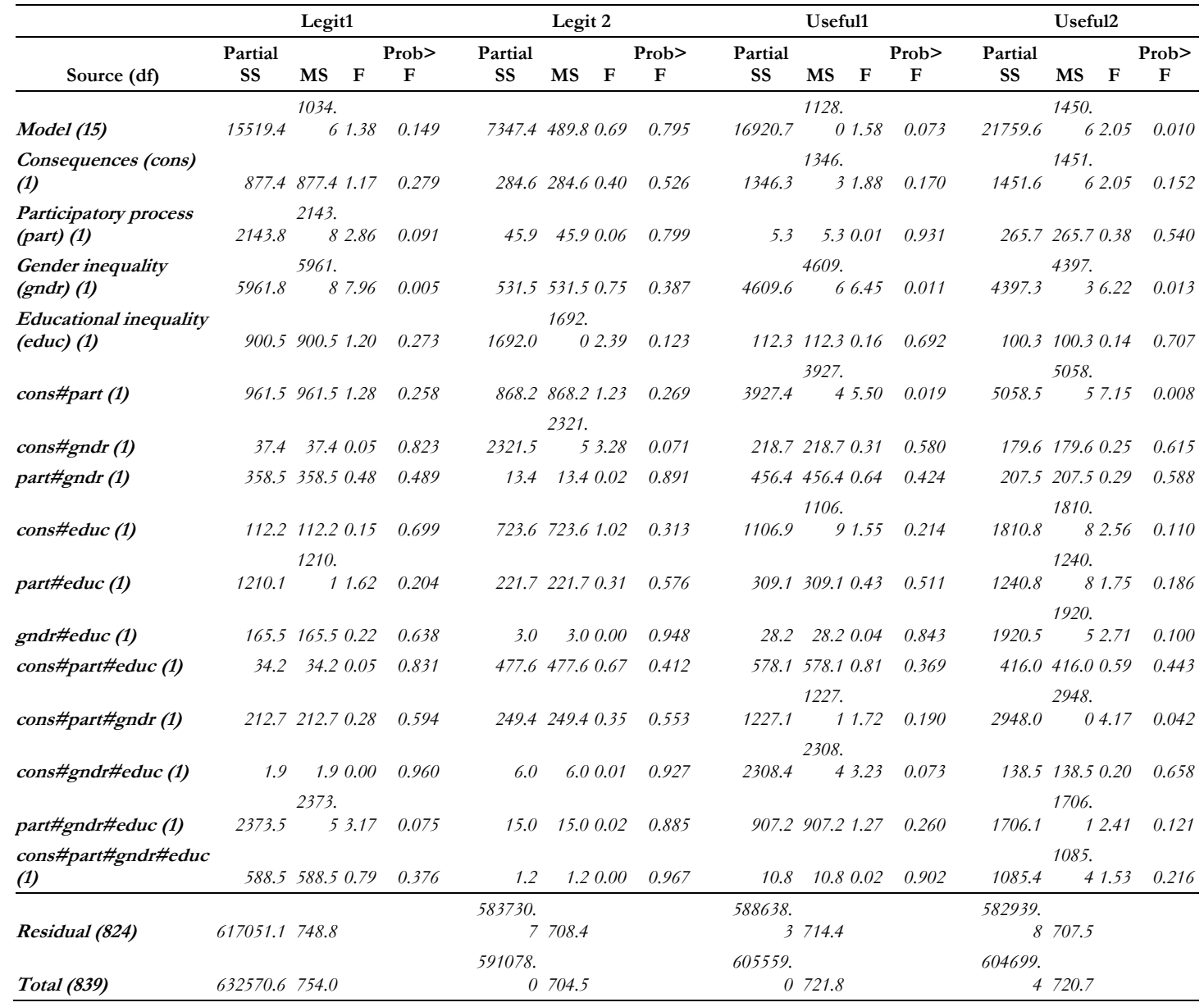

In Table A5 we report ANOVA models that only include the direct effects

Table A5. ANOVA analyses that only include direct effects

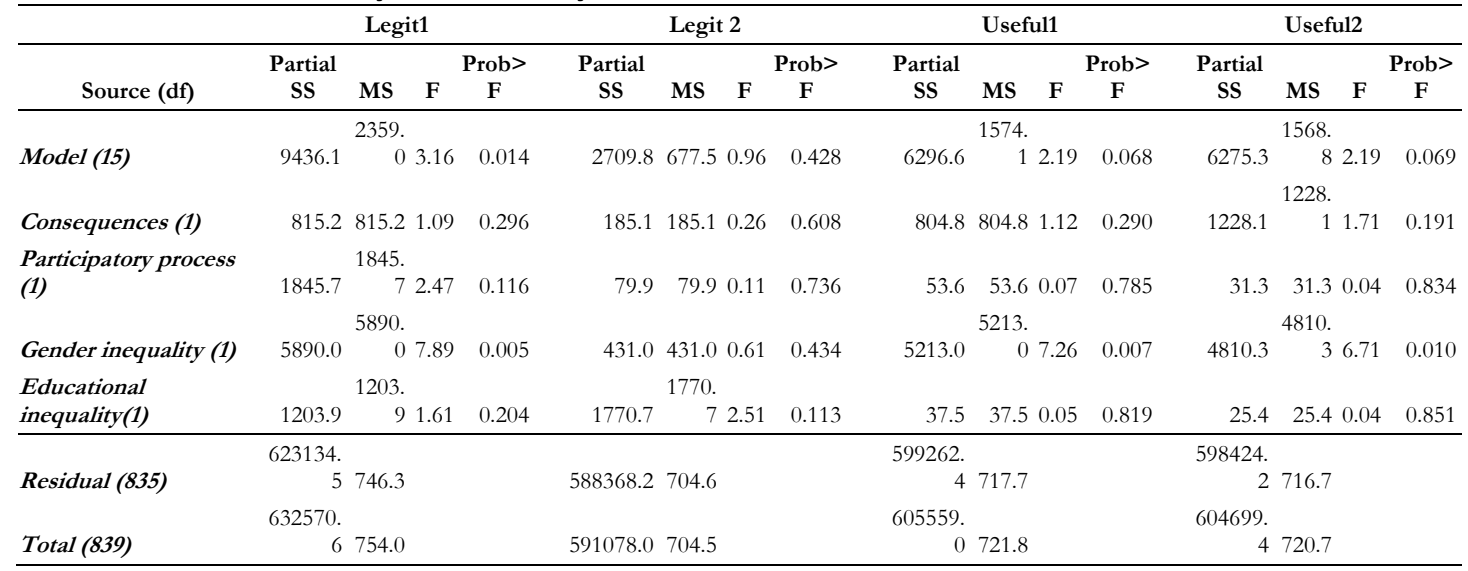


In table A6, we report ANOVA models where we only include the interaction terms that are of primary interest according to our hypotheses.

Table A6. ANOVA models including only relevant interaction terms

\begin{tabular}{|c|c|c|c|c|c|c|c|c|c|c|c|c|c|c|c|c|}
\hline \multirow[b]{2}{*}{ Source (df) } & \multicolumn{4}{|c|}{ Legit1 } & \multicolumn{4}{|c|}{ Legit 2} & \multicolumn{4}{|c|}{ Useful1 } & \multicolumn{4}{|c|}{ Useful2 } \\
\hline & $\begin{array}{l}\text { Partial } \\
\text { SS }\end{array}$ & MS & F & $\begin{array}{l}\text { Prob }> \\
\text { F }\end{array}$ & $\begin{array}{l}\text { Partial } \\
\text { SS }\end{array}$ & MS & F & $\begin{array}{l}\text { Prob }> \\
\text { F }\end{array}$ & $\begin{array}{l}\text { Partial } \\
\text { SS }\end{array}$ & MS & F & $\begin{array}{l}\text { Prob }> \\
\text { F }\end{array}$ & $\begin{array}{l}\text { Partial } \\
\text { SS }\end{array}$ & MS & F & $\begin{array}{l}\text { Prob> } \\
\text { F }\end{array}$ \\
\hline Model (15) & 10978.5 & 1372.3 & 31.83 & 0.067 & 5744.1 & 718.0 & 01.02 & 0.420 & 8293.0 & 1036.6 & 1.44 & 0.175 & 9398.1 & 1174.8 & 1.64 & 0.110 \\
\hline $\begin{array}{l}\text { Consequences } \\
\text { (cons) (1) }\end{array}$ & 863.6 & 863.6 & 61.15 & 0.283 & 250.1 & 250.1 & 10.36 & 0.552 & 770.7 & 770.7 & 1.07 & 0.301 & 1252.3 & 31252.3 & 1.75 & 0.187 \\
\hline $\begin{array}{l}\text { Participatory } \\
\text { process (part) (1) }\end{array}$ & 1678.7 & 1678.7 & 72.24 & 0.135 & 70.9 & 70.9 & 90.10 & 0.751 & 29.1 & 29.1 & 0.04 & 0.841 & 58.9 & 58.9 & 0.08 & 0.775 \\
\hline $\begin{array}{l}\text { Gender inequality } \\
\text { (gndr) (1) }\end{array}$ & 5806.8 & 5806.8 & 87.76 & 0.006 & 491.4 & 491.4 & 40.70 & 0.404 & 5019.6 & 5019.6 & 6.98 & 0.008 & 4555.6 & 4555.6 & 6.36 & 0.012 \\
\hline $\begin{array}{l}\text { Educational } \\
\text { inequality (educ) } \\
\text { (1) }\end{array}$ & 1147.7 & 1147.7 & 71.53 & 0.216 & 1620.5 & $\begin{array}{r}1620 \\
5\end{array}$ & 52.30 & 0.130 & 39.9 & 39.9 & 0.06 & 0.814 & 30.7 & 30.7 & 0.04 & 0.836 \\
\hline cons\#gndr (1) & 27.9 & 27.9 & 90.04 & 0.847 & 2411.3 & $\begin{array}{r}2411 \\
3\end{array}$ & 33.42 & 0.065 & 244.2 & 244.2 & 0.34 & 0.560 & 166.8 & 166.8 & 0.23 & 0.630 \\
\hline part\#gndr (1) & 524.9 & 524.9 & 90.70 & 0.402 & 25.6 & 25.6 & 60.04 & 0.849 & 347.6 & 347.6 & 0.48 & 0.487 & 128.6 & 128.6 & 0.18 & 0.672 \\
\hline cons\#educ (1) & 83.6 & 83.6 & 60.11 & 0.738 & 787.3 & 787.3 & 31.12 & 0.291 & 1117.4 & 1117.4 & 1.55 & 0.213 & 1795.3 & 31795.3 & 2.51 & 0.114 \\
\hline part\#educ (1) & 1098.7 & 1098.7 & 71.47 & 0.226 & 129.0 & 129.0 & 00.18 & 0.669 & 157.0 & 157.0 & 0.22 & 0.640 & 809.6 & 509.6 & 1.13 & 0.288 \\
\hline Residual (831) & $\begin{array}{r}621592 . \\
1\end{array}$ & 748.0 & & & $\begin{array}{r}585333 . \\
9\end{array}$ & 704.4 & & & 597266.0 & 718.7 & & & $\begin{array}{r}595301 . \\
3\end{array}$ & 716.4 & & \\
\hline Total (839) & $\begin{array}{r}632570 . \\
6\end{array}$ & 754.0 & & & $\begin{array}{r}591078 . \\
0\end{array}$ & 704.5 & & & 605559.0 & 721.8 & & & $\begin{array}{r}604699 . \\
4\end{array}$ & 720.7 & & \\
\hline
\end{tabular}

The results are in both cases similar which means that model specification does not decide the results. 


\section{Appendix 5: Attention checks}

Table A7 shows the attention checks and distribution of answers.

Table A7. Attention checks

\begin{tabular}{|c|c|c|c|}
\hline & Freq. & Percent & \# Correct \\
\hline \multicolumn{4}{|c|}{ Who was affected by the legislation } \\
\hline Me personally & 125 & 14.88 & 108 \\
\hline Society at large & 511 & 60.83 & 298 \\
\hline Residents of the USA & 22 & 2.62 & 0 \\
\hline Don't know & 182 & 21.67 & 0 \\
\hline \multicolumn{4}{|c|}{ How did decision-makers get input from participants } \\
\hline Referendum & 297 & 35.4 & 225 \\
\hline Discussion forum & 295 & 35.1 & 239 \\
\hline Survey to all residents & 110 & 13.1 & 0 \\
\hline Don't know & 138 & 16.4 & 0 \\
\hline \multicolumn{4}{|c|}{ What gender were the majority of the participants? } \\
\hline Male & 354 & 42.1 & 311 \\
\hline Female & 287 & 34.2 & 287 \\
\hline Non-binary & 17 & 2 & 0 \\
\hline Don't know & 182 & 21.7 & 0 \\
\hline \multicolumn{4}{|c|}{ What was the level of education of the majority of participants? } \\
\hline University degree & 349 & 41.6 & 302 \\
\hline Basic education & 341 & 40.6 & 290 \\
\hline Educated abroad & 9 & 1.1 & 0 \\
\hline Don't know & 141 & 16.8 & 0 \\
\hline
\end{tabular}

We see that few answered correctly for the consequences of the legislation and the nature of the participatory process. More people remembered correctly when it comes to the types of inequality, although here also about $1 / 3$ of respondents did not recollect the correct answer.

The following Table A8 shows the results when restricting analyses to respondents who answered correctly.

Table A8. ANOVA models

\begin{tabular}{|c|c|c|c|c|c|c|c|c|c|c|c|c|}
\hline \multirow[b]{2}{*}{ Legit 1} & \multicolumn{4}{|c|}{ ALL RESPONDENTS } & \multicolumn{4}{|c|}{$\begin{array}{l}\text { ONLY RESPONDENTS WHO } \\
\text { ANSWERED CORRECT FOR GENDER }\end{array}$} & \multicolumn{4}{|c|}{$\begin{array}{c}\text { ONLY RESPONDENTS WHO } \\
\text { ANSWERED CORRECT FOR } \\
\text { EDUCATION }\end{array}$} \\
\hline & & & & & & & & & & & & \\
\hline Source & Partial SS & MS & $\mathrm{F}$ & Prob $>F$ & Partial SS & MS & $\mathrm{F}$ & Prob $>F$ & Partial SS & MS & $\mathrm{F}$ & Prob $>F$ \\
\hline Model & 15519.4 & 1034.6 & 1.4 & 0.149 & 16405.5 & 1093.7 & 1.4 & 0.141 & 17425.3 & 1161.7 & 1.5 & 0.107 \\
\hline conseq & 877.4 & 877.4 & 1.2 & 0.279 & 1223.2 & 1223.2 & 1.6 & 0.211 & 164.1 & 164.1 & 0.2 & 0.648 \\
\hline particip & 2143.8 & 2143.8 & 2.9 & 0.091 & 1487.3 & 1487.3 & 1.9 & 0.168 & 2524.7 & 2524.7 & 3.2 & 0.074 \\
\hline conseq\#particip & 961.5 & 961.5 & 1.3 & 0.258 & 597.9 & 597.9 & 0.8 & 0.382 & 2137.6 & 2137.6 & 2.7 & 0.100 \\
\hline gendr & 5961.8 & 5961.8 & 8.0 & 0.005 & 4883.9 & 4883.9 & 6.3 & 0.013 & 7013.4 & 7013.4 & 8.9 & 0.003 \\
\hline conseq\#gendr & 37.4 & 37.4 & 0.1 & 0.823 & 1567.7 & 1567.7 & 2.0 & 0.157 & 465.8 & 465.8 & 0.6 & 0.442 \\
\hline particip\#gendr & 358.5 & 358.5 & 0.5 & 0.489 & 587.5 & 587.5 & 0.8 & 0.386 & 251.9 & 251.9 & 0.3 & 0.571 \\
\hline conseq\#particip\#gendr & 212.7 & 212.7 & 0.3 & 0.594 & 64.9 & 64.9 & 0.1 & 0.773 & 0.6 & 0.6 & 0.0 & 0.978 \\
\hline educ & 900.5 & 900.5 & 1.2 & 0.273 & 1.6 & 1.6 & 0.0 & 0.964 & 240.3 & 240.3 & 0.3 & 0.580 \\
\hline conseq\#educ & 112.2 & 112.2 & 0.2 & 0.699 & 5.8 & 5.8 & 0.0 & 0.931 & 132.0 & 132.0 & 0.2 & 0.682 \\
\hline particip\#educ & 1210.1 & 1210.1 & 1.6 & 0.204 & 1888.7 & 1888.7 & 2.4 & 0.120 & 991.9 & 991.9 & 1.3 & 0.262 \\
\hline conseq\#particip\#educ & 34.2 & 34.2 & 0.1 & 0.831 & 169.5 & 169.5 & 0.2 & 0.641 & 236.5 & 236.5 & 0.3 & 0.583 \\
\hline gendr\#educ & 165.5 & 165.5 & 0.2 & 0.638 & 649.5 & 649.5 & 0.8 & 0.362 & 298.0 & 298.0 & 0.4 & 0.538 \\
\hline conseq\#gendr\#educ & 1.9 & 1.9 & 0.0 & 0.960 & 613.5 & 613.5 & 0.8 & 0.376 & 0.1 & 0.1 & 0.0 & 0.993 \\
\hline particip\#gendr\#educ & 2373.5 & 2373.5 & 3.2 & 0.075 & 386.7 & 386.7 & 0.5 & 0.482 & 1745.8 & 1745.8 & 2.2 & 0.137 \\
\hline conseq\#particip\#gendr\#educ & 588.5 & 588.5 & 0.8 & 0.376 & 1220.2 & 1220.2 & 1.6 & 0.212 & 950.4 & 950.4 & 1.2 & 0.272 \\
\hline Residual & 617051.1 & 748.8 & & & 443451.4 & 780.7 & & & 452291.2 & 785.2 & & \\
\hline
\end{tabular}




\begin{tabular}{|c|c|c|c|c|c|c|c|c|c|c|c|c|}
\hline \multirow[b]{2}{*}{ Total } & \multicolumn{4}{|c|}{ ALL RESPONDENTS } & \multicolumn{4}{|c|}{$\begin{array}{l}\text { ONLY RESPONDENTS WHO } \\
\text { ANSWERED CORRECT FOR GENDER }\end{array}$} & \multicolumn{4}{|c|}{$\begin{array}{c}\text { ONLY RESPONDENTS WHO } \\
\text { ANSWERED CORRECT FOR } \\
\text { EDUCATION }\end{array}$} \\
\hline & 632570.6 & 754.0 & & & 459856.8 & 788.8 & & & 469716.5 & 794.8 & & \\
\hline \multicolumn{13}{|l|}{ Legit 2} \\
\hline Source & Partial SS & MS & $\mathrm{F}$ & Prob $>F$ & Partial SS & MS & $\mathrm{F}$ & Prob $>F$ & Partial SS & MS & $\mathrm{F}$ & Prob $>F$ \\
\hline Model & 7347.4 & 489.8 & 0.7 & 0.795 & 7116.6 & 474.4 & 0.7 & 0.785 & 9221.7 & 614.8 & 0.9 & 0.563 \\
\hline conseq & 284.6 & 284.6 & 0.4 & 0.526 & 87.5 & 87.5 & 0.1 & 0.719 & 38.9 & 38.9 & 0.1 & 0.811 \\
\hline particip & 45.9 & 45.9 & 0.1 & 0.799 & 19.7 & 19.7 & 0.0 & 0.865 & 15.5 & 15.5 & 0.0 & 0.880 \\
\hline conseq\#particip & 868.2 & 868.2 & 1.2 & 0.269 & 608.6 & 608.6 & 0.9 & 0.343 & 448.8 & 448.8 & 0.7 & 0.418 \\
\hline gendr & 531.5 & 531.5 & 0.8 & 0.387 & 125.0 & 125.0 & 0.2 & 0.668 & 239.4 & 239.4 & 0.4 & 0.554 \\
\hline conseq\#gendr & 2321.5 & 2321.5 & 3.3 & 0.071 & 316.5 & 316.5 & 0.5 & 0.494 & 1410.5 & 1410.5 & 2.1 & 0.151 \\
\hline particip\#gendr & 13.4 & 13.4 & 0.0 & 0.891 & 132.5 & 132.5 & 0.2 & 0.658 & 210.3 & 210.3 & 0.3 & 0.579 \\
\hline conseq\#particip\#gendr & 249.4 & 249.4 & 0.4 & 0.553 & 687.7 & 687.7 & 1.0 & 0.314 & 92.0 & 92.0 & 0.1 & 0.714 \\
\hline educ & 1692.0 & 1692.0 & 2.4 & 0.123 & 2255.8 & 2255.8 & 3.3 & 0.068 & 3037.4 & 3037.4 & 4.5 & 0.035 \\
\hline conseq\#educ & 723.6 & 723.6 & 1.0 & 0.313 & 103.4 & 103.4 & 0.2 & 0.696 & 51.0 & 51.0 & 0.1 & 0.785 \\
\hline particip\#educ & 221.7 & 221.7 & 0.3 & 0.576 & 1315.4 & 1315.4 & 1.9 & 0.164 & 489.3 & 489.3 & 0.7 & 0.398 \\
\hline conseq\#particip\#educ & 477.6 & 477.6 & 0.7 & 0.412 & 571.6 & 571.6 & 0.8 & 0.359 & 377.0 & 377.0 & 0.6 & 0.458 \\
\hline gendr\#educ & 3.0 & 3.0 & 0.0 & 0.948 & 289.3 & 289.3 & 0.4 & 0.514 & 4.0 & 4.0 & 0.0 & 0.939 \\
\hline conseq\#gendr\#educ & 6.0 & 6.0 & 0.0 & 0.927 & 42.2 & 42.2 & 0.1 & 0.803 & 97.3 & 97.3 & 0.1 & 0.706 \\
\hline particip\#gendr\#educ & 15.0 & 15.0 & 0.0 & 0.885 & 651.8 & 651.8 & 1.0 & 0.327 & 1706.6 & 1706.6 & 2.5 & 0.114 \\
\hline conseq\#particip\#gendr\#educ & 1.2 & 1.2 & 0.0 & 0.967 & 28.7 & 28.7 & 0.0 & 0.837 & 74.3 & 74.3 & 0.1 & 0.742 \\
\hline Residual & 583730.7 & 708.4 & & & 384479.7 & 676.9 & & & 393090.6 & 682.4 & & \\
\hline Total & 591078.0 & 704.5 & & & 391596.3 & 671.7 & & & 402312.3 & 680.7 & & \\
\hline \multicolumn{13}{|l|}{ Useful 1} \\
\hline Source & Partial SS & MS & $\mathrm{F}$ & Prob $>F$ & $\mathrm{df}$ & $\mathrm{F}$ & Prob $>F$ & & Partial SS & MS & $\mathrm{F}$ & Prob $>F$ \\
\hline Model & 16920.7 & 1128.0 & 1.6 & 0.073 & 15641.9 & 1042.8 & $\begin{array}{ll}3 & 1.4\end{array}$ & 0.142 & 17172.3 & 1144.8 & 1.5 & 0.085 \\
\hline conseq & 1346.3 & 1346.3 & 1.9 & 0.170 & 1874.6 & 1874.6 & 2.5 & 0.113 & 538.0 & 538.0 & 0.7 & 0.395 \\
\hline particip & 5.3 & 5.3 & 0.0 & 0.931 & 126.4 & 126.4 & 0.2 & 0.681 & 227.4 & 227.4 & 0.3 & 0.580 \\
\hline conseq\#particip & 3927.4 & 3927.4 & 5.5 & 0.019 & 2141.2 & 2141.2 & 2.9 & 0.091 & 3074.5 & 3074.5 & 4.2 & 0.042 \\
\hline gendr & 4609.6 & 4609.6 & 6.5 & 0.011 & 3361.4 & 3361.4 & 4.5 & 0.034 & 5236.0 & 5236.0 & 7.1 & 0.008 \\
\hline conseq\#gendr & 218.7 & 218.7 & 0.3 & 0.580 & 1.3 & 1.3 & 0.0 & 0.967 & 494.1 & 494.1 & 0.7 & 0.415 \\
\hline particip\#gendr & 456.4 & 456.4 & 0.6 & 0.424 & 40.8 & 40.8 & 0.1 & 0.815 & 1.8 & 1.8 & 0.0 & 0.961 \\
\hline conseq\#particip\#gendr & 1227.1 & 1227.1 & 1.7 & 0.190 & 1838.8 & 1838.8 & 2.5 & 0.117 & 1279.3 & 1279.3 & 1.7 & 0.190 \\
\hline educ & 112.3 & 112.3 & 0.2 & 0.692 & 783.4 & 783.4 & 1.1 & 0.306 & 656.8 & 656.8 & 0.9 & 0.347 \\
\hline conseq\#educ & 1106.9 & 1106.9 & 1.6 & 0.214 & 2134.2 & 2134.2 & 2.9 & 0.091 & 1171.9 & 1171.9 & 1.6 & 0.209 \\
\hline particip\#educ & 309.1 & 309.1 & 0.4 & 0.511 & 473.4 & 473.4 & 0.6 & 0.426 & 158.8 & 158.8 & 0.2 & 0.644 \\
\hline conseq\#particip\#educ & 578.1 & 578.1 & 0.8 & 0.369 & 1088.2 & 1088.2 & 1.5 & 0.228 & 1045.7 & 1045.7 & 1.4 & 0.235 \\
\hline gendr\#educ & 28.2 & 28.2 & 0.0 & 0.843 & 47.7 & 47.7 & 0.1 & 0.800 & 8.8 & 8.8 & 0.0 & 0.913 \\
\hline conseq\#gendr\#educ & 2308.4 & 2308.4 & 3.2 & 0.073 & 1090.9 & 1090.9 & 1.5 & 0.227 & 2081.7 & 2081.7 & 2.8 & 0.094 \\
\hline particip\#gendr\#educ & 907.2 & 907.2 & 1.3 & 0.260 & 468.7 & 468.7 & 0.6 & 0.428 & 751.5 & 751.5 & 1.0 & 0.314 \\
\hline conseq\#particip\#gendr\#educ & 10.8 & 10.8 & 0.0 & 0.902 & 114.6 & 114.6 & 0.2 & 0.695 & 112.1 & 112.1 & 0.2 & 0.697 \\
\hline Residual & 588638.3 & 714.4 & & & 423651.5 & 745.9 & & & 426931.6 & 741.2 & & \\
\hline Total & 605559.0 & 721.8 & & & 439293.4 & 753.5 & & & 444103.9 & 751.4 & & \\
\hline \multicolumn{13}{|l|}{ Useful2 } \\
\hline Source & Partial SS & MS & $\mathrm{F}$ & Prob $>F$ & Partial SS & MS & $\mathrm{F}$ & Prob $>F$ & Partial SS & MS & $\mathrm{F}$ & Prob $>F$ \\
\hline Model & 21759.6 & 1450.6 & 2.1 & 0.010 & 19463.9 & 1297.6 & 1.8 & 0.027 & 21623.3 & 1441.6 & 2.1 & 0.011 \\
\hline conseq & 1451.6 & 1451.6 & 2.1 & 0.152 & 748.2 & 748.2 & 1.1 & 0.304 & 62.9 & 62.9 & 0.1 & 0.765 \\
\hline particip & 265.7 & 265.7 & 0.4 & 0.540 & 134.3 & 134.3 & 0.2 & 0.663 & 410.5 & 410.5 & 0.6 & 0.446 \\
\hline conseq\#particip & 5058.5 & 5058.5 & 7.2 & 0.008 & 2826.9 & 2826.9 & 4.0 & 0.046 & 4074.3 & 4074.3 & 5.8 & 0.017 \\
\hline gendr & 4397.3 & 4397.3 & 6.2 & 0.013 & 4331.1 & 4331.1 & 6.1 & 0.014 & 5135.4 & 5135.4 & 7.3 & 0.007 \\
\hline conseq\#gendr & 179.6 & 179.6 & 0.3 & 0.615 & 19.0 & 19.0 & 0.0 & 0.870 & 457.1 & 457.1 & 0.7 & 0.421 \\
\hline particip\#gendr & 207.5 & 207.5 & 0.3 & 0.588 & 2.7 & 2.7 & 0.0 & 0.951 & 2.5 & 2.5 & 0.0 & 0.953 \\
\hline conseq\#particip\#gendr & 2948.0 & 2948.0 & 4.2 & 0.042 & 4241.8 & 4241.8 & 6.0 & 0.015 & 2118.1 & 2118.1 & 3.0 & 0.083 \\
\hline educ & 100.3 & 100.3 & 0.1 & 0.707 & 488.7 & 488.7 & 0.7 & 0.406 & 1999.5 & 1999.5 & 2.8 & 0.093 \\
\hline conseq\#educ & 1810.8 & 1810.8 & 2.6 & 0.110 & 2217.3 & 2217.3 & 3.1 & 0.077 & 1858.7 & 1858.7 & 2.6 & 0.105 \\
\hline particip\#educ & 1240.8 & 1240.8 & 1.8 & 0.186 & 313.9 & 313.9 & 0.4 & 0.505 & 153.0 & 153.0 & 0.2 & 0.641 \\
\hline conseq\#particip\#educ & 416.0 & 416.0 & 0.6 & 0.443 & 441.1 & 441.1 & 0.6 & 0.430 & 751.7 & 751.7 & 1.1 & 0.302 \\
\hline gendr\#educ & 1920.5 & 1920.5 & 2.7 & 0.100 & 2075.6 & 2075.6 & 2.9 & 0.087 & 2224.7 & 2224.7 & 3.2 & 0.076 \\
\hline conseq\#gendr\#educ & 138.5 & 138.5 & 0.2 & 0.658 & 29.3 & 29.3 & 0.0 & 0.839 & 459.4 & 459.4 & 0.7 & 0.420 \\
\hline particip\#gendr\#educ & 1706.1 & 1706.1 & 2.4 & 0.121 & 852.7 & 852.7 & 1.2 & 0.273 & 913.6 & 913.6 & 1.3 & 0.255 \\
\hline conseq\#particip\#gendr\#educ & 1085.4 & 1085.4 & 1.5 & 0.216 & 308.1 & 308.1 & 0.4 & 0.509 & 376.1 & 376.1 & 0.5 & 0.465 \\
\hline Residual & 582939.8 & 707.5 & & & 401507.3 & 706.9 & & & 405620.7 & 704.2 & & \\
\hline Total & 604699.4 & 720.7 & & & 420971.2 & 722.1 & & & 427244.1 & 722.9 & & \\
\hline
\end{tabular}


The results are largely similar regardless of the restriction since gender inequality preserves the only inequality to consistently affect legitimacy and the interaction terms do not reach significance. 